\title{
En los mayores peligros se conoce la amistad, auto sacramental de José de Valdivielso, representado en el Corpus hispalense de 1619. Estudio y reconstrucción virtual
}

En los mayores peligros se conoce la amistad (Friendship is Best Acknowledged when in Danger), an Auto Sacramental (Eucharistic Morality Play) by José de Valdivielso, Staged at the Corpus Christi Feast in Seville, in 1619. An Analysis and a Virtual Reconstruction

\section{Mercedes de los Reyes Peña}

Universidad de Sevilla

ESPAÑA

mdelosreyesp@telefonica.net

\section{Vicente Palacios}

Escenógrafo de Alquivira Diseño y Producción ESPAÑA

alquivira@gmail.com

[Hipogrifo, (issn: 2328-1308), 5.2, 2017, pp. 11-42]

Recibido: 03-04-2017 / Aceptado: 02-05-2017

DOI: http://dx.doi.org/10.13035/H.2017.05.02.03

Resumen. El artículo se centra en el estudio de uno de los cinco autos sacramentales representados en el Corpus hispalense de 1619. Se trata del auto En los mayores peligros se conoce la amistad, del dramaturgo José de Valdivielso, por el autor de comedias Diego de Vallejo. Titulado también La amistad en el peligro, ca- 
rece de edición crítica a la luz de los modernos criterios de la filología y cuenta con dos testimonios impresos en vida del escritor (1622 y 1624) y dos manuscritos con letra del siglo XVII. Se presenta en el contexto histórico-religioso y urbano de la citada festividad, a base de la documentación conservada, y se recrea virtualmente su puesta en escena sobre carros y su recorrido por las calles y plazas de la ciudad.

Palabras clave. Auto sacramental; Sevilla; Corpus de 1619; José de Valdivielso; En los mayores peligros se conoce la amistad; La amistad en el peligro; contexto histórico-religioso y urbano; fiesta; carros; puesta en escena virtual.

Abstract. This paper studies José de Valdivielso's En los mayores peligros se conoce la amistad (Friendship is best acknowledged when in danger) one of the five autos sacramentales (Eucharistic morality plays) staged at the Corpus Christi feast in Seville, in 1619, by Diego de Vallejo. It also bears the title La amistad en el peligro (Friendship when in danger), and has never been published in a modern critical edition, though two published records (1622 and 1624) bear witness to the play, of which there are two 17 th Century manuscript versions extant. This article, based on contemporary records, studies the historical socio-religious-urban context of the Corpus Christi feast in Seville and virtually reconstructs the play's performance, on pageant wagons, and its subsequent procession within the town.

Keywords. Auto sacramental (Eucharistic Morality Play); Seville; Corpus Christi in 1619; José de Valdivielso; En los mayores peligros se conoce la amistad (Friendship is best acknowledged when in danger); Historical Socio-Religious-Urban Context; Feast; Pageant Wagons; Virtual Performance.

Quizá pueda sorprender que en las investigaciones de Piedad Bolaños Donoso (Universidad de Sevilla) y Mercedes de los Reyes Peña sobre la festividad del Corpus Christi en Sevilla durante la segunda mitad del siglo XVI y primera del siglo XVII, período de extraordinaria actividad espectacular para la celebración de la fiesta, nunca nos hayamos detenido en el Corpus de 1619. La razón principal ha estribado en que su documentación no era totalmente inédita, pues había sido exhumada en parte por estudiosos como José Sánchez-Arjona' y Jean Sentaurens $^{2}$, sin ofrecernos en primicia la novedad y atractivo que poseían otros años. Sin embargo, la aplicación de la tecnología informática a las Humanidades y su ingerencia en el rumbo de nuestra investigación, propiciaron volver la mirada hacia el citado Corpus, en el que solo alguna vez habíamos incidido de forma tangencial ${ }^{3}$, hasta convertirlo en objeto de estudio del grupo de investigación «Teatro Siglo de Oro (Bolaños - De los Reyes - Palacios - Ruesga)» $»^{4}$. Nos hallamos en una primera fase del proyecto, siendo posible ofrecer ya algunos resultados, cuyo conjunto

1. Noticias referentes a los anales del teatro en Sevilla desde Lope de Rueda hasta fines del siglo XVII.

2. Sentaurens, 1984.

3. Reyes Peña, 1993.

4. Grupo de investigación integrado por Piedad Bolaños Donoso (Universidad de Sevilla), Mercedes de los Reyes Peña (Universidad de Sevilla), Vicente Palacios (Escenógrafo) y Juan Ruesga (Arquitecto 
será más extenso y detallado cuando lo conformen la totalidad y armonización de todos sus componentes.

El día del Corpus Christi de 1619 fue el jueves 30 de mayo. Desde bastante antes, el Cabildo municipal comenzará, como era habitual, con los preparativos de la fiesta. Su financiación y las disposiciones de una comisión de diputados nombrada al efecto, transformarán efímeramente una parte de la urbe para acoger en sus calles y plazas no solo al Santísimo Sacramento, sino también a una serie de carros de representación, danzas y figuras grotescas que, recorriendo el itinerario de la procesión, convertirán lo teatral y lo parateatral en un público, colorista y festivo homenaje a la Eucaristía.

Este continuo devenir municipal en torno a la fiesta queda reflejado a partir del mes de febrero en las actas capitulares, libros de caja, libranzas emitidas, memorias de compañías, peticiones, escrituras de obligación, acuerdos, remate del adobio y reparo de los carros, condiciones para las invenciones de los autos y las casas y tramoyas, empedrados, toldos y pinos, juncia, cera, muestra de carros y danzas, joya..., documentos todos conservados en el caso del «Corpus de 1619» y radicados en el Archivo Municipal de Sevilla (AMS), como ocurre con otros años. La mayor parte de la documentación generada se halla agrupada en una especie de cuadernillo -al que denominaremos Cuadernillo del Corpus de 1619-, que permite seguir día a día el desarrollo de los distintos componentes de la fiesta. No obstante, la suerte de contar con este Cuadernillo, queda empañada por la dificultad de su lectura, a causa de la disolución de la tinta que mancha el papel y deja fragmentos de imposible lectura ${ }^{5}$.

Como ya indicaba Sánchez-Arjona en sus noticias sobre este Corpus ${ }^{6}$, los autos representados fueron cinco, en lugar de cuatro como había sucedido en años anteriores. Estuvieron a cargo de tres compañías, capitaneadas por los autores de comedias Diego de Vallejo, Juan Acacio y Cristóbal Ortiz. Vallejo representó El robo de Elena y En los mayores peligros se conoce la amistad; Acacio, La ninfa del cielo y La serrana de Plasencia; y Ortiz, El príncipe de la luz y el lucero de la noche o El príncipe de la paz.

De estos cinco autos, en este trabajo nos detendremos solo en uno, que situaremos en el contexto de la festividad, recreando virtualmente su puesta en escena y su recorrido por las calles y plazas de la ciudad. Se trata del auto En los mayores peligros se conoce la amistad, uno de los dos encargados a Vallejo, autor que presenta a la ciudad la siguiente memoria de su compañía, dejando en la lista estampada su firma:

y Escenógrafo). Los resultados hasta ahora obtenidos pueden consultarse en la página web: <http:// investigacionteatrosiglodeoro.com/> [10/10/2017]

5. AMS, Sección XIII, Papeles importantes del siglo XVII, t. II, doc. núm. 36, fols. 178r-302r [foliación moderna a lápiz]. En adelante, nos referiremos a él como Cuadernillo del Corpus de 1619. En el fol. 178r, figuran los nombres de los caballeros diputados integrantes este año de la comisión para la fiesta, a la que aludíamos más arriba.

6. Noticias referentes a los anales del teatro en Sevilla desde Lope de Rueda hasta fines del siglo XVII, pp. 195-210 [«Año 1619»]. 
Diego de Vallejo, el autor.

Manuel de Vallejo, su hijo, y Francisca María, su mujer [de Diego de Vallejo].

Mariana de Alarcón, viuda.

Segundo de Morales y Leocadia de Torres, su mujer.

Diego de Ortega y Ana María de Peralta, su mujer.

Miguel de Barbosa e Isabel de Acosta, su mujer.

Juan de Valdivielso.

Jusepe del Peral, músico y bailarín.

Juan de Arce, músico.

Manuel de Ribas.

Juan de Montoya

Pedro de Salazar.

Diego Vallejo [firma y rúbrica]

Como se aprecia, está integrada por un total de 16 miembros: once hombres y cinco mujeres. Este elenco va seguido de una petición del autor a la ciudad, en la que solicita tomar parte en la fiesta, sin querer responder ni aceptar una demanda hecha desde Granada hasta conocer el parecer de la institución sevillana. La citada petición se lee en el cabildo de 21 de febrero y se ordena que le den la mitad de la fiesta, haciendo con él la correspondiente escritura de obligación y dándole lo que se suele librar ${ }^{8}$.

La firma de la escritura no se hace esperar, pues se suscribe el 22 de febrero. Como otorgantes, figuran el autor de comedias y los miembros de su compañía, precisándose sus respectivos lugares de procedencia, estancia y funciones en la misma:

Sepan cuantos esta carta vieren como yo, Diego de Vallejo, autor de comedias, vecino desta ciudad de Sevilla en Triana, como principal debdor e obligado, e nos Manuel de Vallejo, su hijo, y Francisca María, su mujer, vecinos de la villa de Madrid, estantes en esta dicha ciudad, e Mariana de Alarcón, viuda, mujer que fue de Alexandre Mazo, difunto, vecina de la ciudad de Valencia, estante en esta ciudad, e Segundo de Morales, representante, e Leocadia de Torres, su mujer, vecinos de la villa de Madrid, estantes en esta dicha ciudad, y Diego de Ortega y Ana María de Peralta, su mujer, representantes, vecinos de la Mota del Cuervo en La Mancha, estantes en esta dicha ciudad, y Miguel Barbosa e Isabel de Acosta, su mujer, músicos, vecinos de la ciudad de Lisboa, estantes en esta dicha ciudad, e Juan de Valdivielso, representante, vecino de la villa de Madrid, estante en esta dicha ciudad, y Jusepe del Peral, músico y bailarín, vecino de la ciudad de Toledo, estante en esta dicha ciudad, y Manuel de Ribas, representante, vecino de la ciudad de Placencia, estante en esta dicha ciudad, y Juan de Montoya, representante, vecino de la villa de Orgás, estante en esta dicha ciudad, y Juan de Arce, músico, vecino de la ciudad de Salamanca, es-

7. «Memoria de la gente de la compañía de Diego de Vallejo, autor de comedias», Cuadernillo del Corpus de 1619, fol. 179r. Dado el criterio editorial seguido por el Grupo de Investigación GRISO, modernizamos las transcripciones de los documentos, respetando las características propias de la época en los tres niveles del signo lingüístico. Esta lista de compañía fue publicada por Sánchez-Arjona, Noticias referentes a los anales del teatro en Sevilla desde Lope de Rueda hasta fines del siglo XVII, p. 203, y Sentaurens, 1984, vol. II, p. 1242. Transcribimos por el original.

8. Cuadernillo del Corpus de 1679, fol. 180r-v. 
tante en esta ciudad, y Pedro de Salazar, representante, vecino de la villa de Madrid, estante en esta dicha ciudad, [...] prometemos e nos obligamos... ${ }^{9}$

La diversa fluidez en los trazos de las letras y rúbricas de sus respectivas firmas, registradas al final del documento notarial, es signo evidente del mayor o menor dominio de la escritura por los actores y, muy plausiblemente, de la lectura y de la formación cultural de este elenco de comediantes.

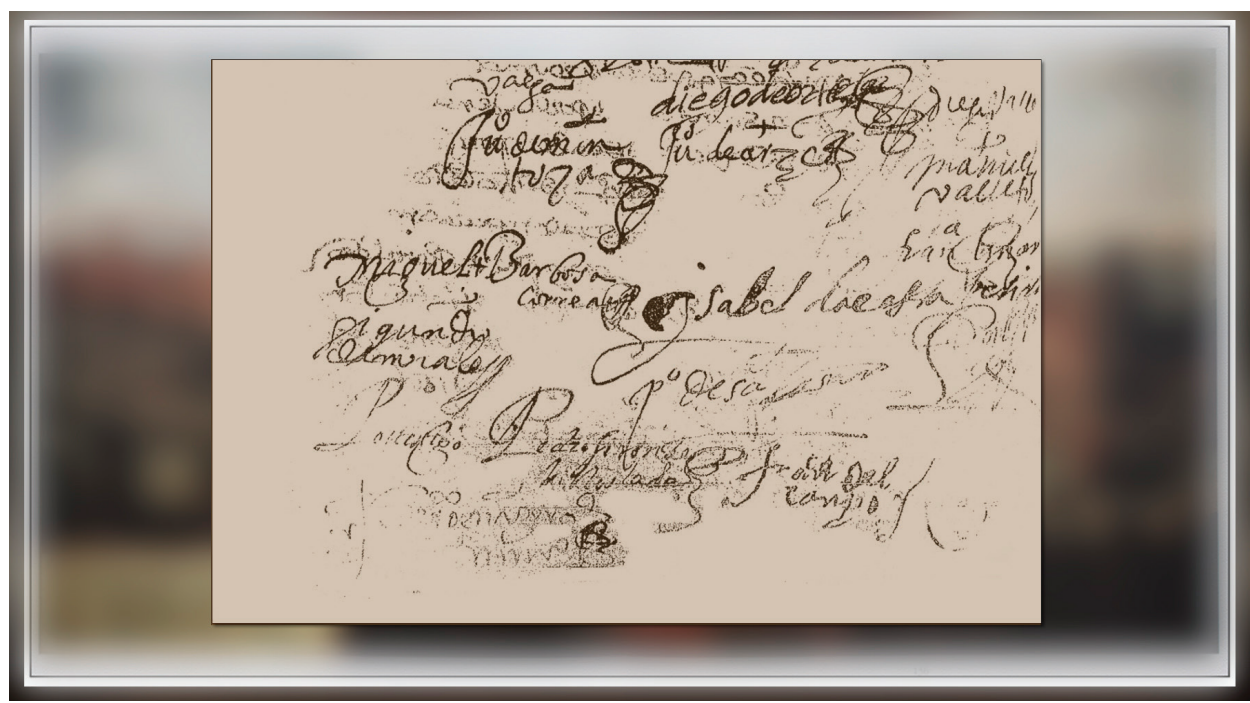

Imagen I

Las condiciones de contratación quedan detalladas en la escritura, como era costumbre, y se repetían año tras año con muy ligeras variantes, sin dejar nada a la improvisación. Era necesario controlar todo para la mayor brillantez de la fiesta, cuyo boato, además de servir para honrar al Sacramento, tenía una finalidad política, al servicio en este caso de la mostración del poder municipal, en competencia con otras ciudades del ámbito peninsular. Era una manifestación más de la estrecha y recíproca relación entre política y religión o religión y política propia del período barroco.

Aunque estas condiciones sean conocidas por ser casi siempre las mismas, deseamos presentarlas aquí bajo la formulación que adquieren en el contrato de la ciudad con Diego de Vallejo. En él, los comediantes se comprometen a hacer dos autos de representación, por el precio de 700 ducados (350 ducados por cada uno de ellos), «en dos carros que para este efeto nos ha de dar la dicha ciudad e caballeros diputados de la dicha fiesta, de las letras y apariencias, y por la orden y forma, y según y con las calidades presisas de obligaciones que se contienen y declaran en las condiciones con que esta dicha ciudad y los caballeros diputados della ordenan se haga» ${ }^{10}$. 
Si los carros los facilitará la ciudad, que ha de darlos «armados y corrientes con la pintura e invenciones que suelen menester a propósito de las dichas representaciones en la forma que yo [Vallejo] lo pidiere» ${ }^{11}$, a costa del autor correrán las letras de los autos y todos los gastos correspondientes a la representación, sometiéndose siempre al parecer de la ciudad y los diputados de la fiesta. Ante ellos, Vallejo se compromete a dar la «muestra» para corregir todo lo que se le ordenare:

cuyas letras [de los autos] yo el dicho Diego Vallejo daré a la dicha cibdad y su comisión y diputados en su nombre, porque han de ser a su contento e satisfación, e yo el dicho Diego Vallejo he de costear los dichos autos y representación dellos, haciendo para su efeto los vestidos, ornatos y aparato e todas las demás cosas y calidades nescesarias de terciopelo, damasco, tela de oro y plata, e todas las demás cosas que fueren nescesarias, todo ello nuevo y aderezado muy a propósito e perfetamente según las figuras que dellos se ovieren de vestir y a el modo y efetos de representación, e todo ello muy a contento y satisfación desta dicha ciudad y de los caballeros diputados de la dicha fiesta y, para esto, daremos la muestra y ensayo de los dichos c[arros], autos y vestidos y trajes... ${ }^{12}$

De la competencia del autor, era también el traslado de los carros hasta la catedral desde el lugar donde se disponían (la plaza situada entre ésta, las murallas del Alcázar y la Lonja, que se vallaba para ocultarlos durante su preparación a las curiosas miradas de los viandantes), así como su devolución, terminadas las representaciones, «a el atarazana de la ciudad o a la parte que fuere señalado por los dichos señores diputados» $»^{13}$. Los carros solían ser empujados por hombres ${ }^{14}$, pero también se dejaba abierta la posibilidad de la utilización de bueyes, como se advierte en la escritura: «y, si a la comisión y diputados les paresciere que los dichos carros [se] hayan de tirar con bueyes, yo el dicho Diego de Vallejo tan solamente he de pagar lo que se suele y acostumbra» ${ }^{15}$. Sin embargo, como indica Sentaurens, esta idea no fue puesta en práctica probablemente por el temor del aspecto poco decoroso que habrían revestido semejantes carros un día de Corpus ${ }^{16}$. A ello, podríamos

11. Cuadernillo del Corpus de 1679, fol. 183r.

12. Cuadernillo del Corpus de 1619, fol. 182v.

13. Cuadernillo del Corpus de 1619, fol. 183v.

14. En el Cuadernillo del Corpus de 1639 (AMS, Sección XIII, Papeles importantes del siglo XVII, t. II, doc. núm. 37 [foliación moderna a lápiz], figura un documento sobre «La obligación de la rodada de los carros» (fol. 347r), donde leemos: «Hase de obligar Amador Gonsales y compañeros a que con veinte y cuatro hombres asistirá a rodar los carros el día de la fiesta del Corpus, dende la víspera a ensebar los ejes y ruedas para que estén prestos en caminar y el día a el amaneser ha de llevallos en la forma que les ordenaren hasta el sitio de los dos Cabildos y de allí illos llevando a la Real Abdiensia sin que en la una parte ni en la otra haya dilasión, no faltando hasta el último carro que acabe su representasión. Y el lunes adelante han de asistir desde las nueve de la mañana a poner los carros delante del corredor del Cabildo y desde allí illos llevando a la Real Abdiensia y asistir hasta que se acaben en esta parte y ponellos en la dicha plasa aquella noche detrás de la pila que es donde se desbaratan, asistiendo siempre con el maestro mayor, y, habiendo cumplido con su obligasión y sertificación del maestro mayor, se le dará la mitad de cuatrosientos reales que es el presio en que todos los años los ruedan y los dusientos antes que pongan mano en los dichos carros».

15. Cuadernillo del Corpus de 1619, fol. 183v.

16. Sentaurens, 1984, t. II, p. 851 
añadir las dificultades y el paso de tiempo que conllevarían el desenganche de los bueyes para las representaciones y la vuelta a su enganche para continuar el desplazamiento por la ciudad.

Los carros, con sus decorados y los actores de sus respectivos autos, los cuales no podían abandonar su carro para ir a representar, cantar o bailar a otro -como queda claramente estipulado bajo las penas correspondientes-, seguían el mismo itinerario que la procesión, deteniéndose en determinados lugares para las representaciones. Éstas no se limitaban a las dos del día del Corpus (la primera, ante el Santísimo Sacramento, delante de la puerta principal de la Iglesia mayor, destinada a ambos cabildos, catedralicio y municipal; y la segunda, en la Plaza de San Francisco, delante de la Audiencia), pues los autores se comprometían a otras durante la Octava:

a la cibdad en la Plaza de San Francisco delante de las casas de su cabildo en la parte y lugar que me fuere mandado el lunes siguiente de la dicha fiesta y ansimismo un día de la otava, y haré la representación de los dichos carros a los señores inquisidores en el castillo o en la parte y lugar que me fuere mandado, siendo por la mañana ${ }^{17}$.

Durante el recorrido de los carros por las calles de la ciudad, podían ocurrir incidentes, cuya resolución ya estaba prevista en las escrituras para mantener el orden y que estos accidentes fortuitos no empañaran el esplendor de la fiesta:

con que, si por razón de quebrarse algún carro e no pudiere pasar y continuar todas las calles, he [Vallejo] de haber cumplido con [1]legar hasta el lugar donde se quebrare y con esperar dos horas con toda la gente y ornato de la dicha representación para que se pueda aderezar el tal carro que así se quebrare y, aderezándose, he de proseguir e pasar por todas las calles hasta que de la dicha campana dé la oración; y, si se quebrare alguna rueda viniendo detrás otro carro que haya menester pasar delante, si se quebrare en la calle de Génova, lo he de sacar a la Plaza de San Francisco, y, si fuere en la calle de la Sierpe, a la entrada de lo ancho de la dicha calle o a la entrada de la dicha Plaza de San Francisco, y, si fuere a los Hileros, lo sacaré a la placeta que está frontero de la Botica para proseguir la representación de los dichos carros ${ }^{18}$.

Para evitar imprevistos de otra naturaleza, los comediantes se obligaban a no «poder vender, ni enajenar, ni obligar, ni hipotecar ni disponer» de los vestidos, ropas y ornatos de la dicha compañía y de los que de nuevo se hicieren para la representación de los dichos autos hasta que hubieran cumplido el contenido de la escritura, así como a estar en la ciudad veinte días antes del Corpus, para dar el ensayo, siempre bajo la aplicación de las correspondientes sanciones si hicieren lo contrario ${ }^{19}$.

La forma de pago también se especifica en la carta de obligación: los 700 ducados percibidos por ambos autos se dividirán en tres partes: 350 ducados a la firma del contrato; 175, tras la muestra; y los 175 restantes, acabadas las representaciones.

17. Cuadernillo del Corpus de 1679, fol. 184r.

18. Cuadernillo del Corpus de 1619, fols. 183v-184r.

19. Cuadernillo del Corpus de 1619, fols. 186v-187r. 
Sin embargo, las deficientes condiciones económicas en las que solían moverse las compañías impulsan a Vallejo, después de haber recibido los primeros 350 ducados en la firma de la escritura, a solicitar a la ciudad un adelanto de 2.000 reales:

porque yo me voy a comensar fuera desta ciudad e, para cuando vuelva tenga fechos todos los vestidos que son menester para la dicha fiesta y los pueda hacer con más comodida[d] y sin sacarlos fia[dos], V. S. ${ }^{a}$ ha de ser servido de mandar se me libren dos mil reales, obligándome y según y en la forma que se hizo agora un año ${ }^{20}$.

Adelanto que se le concede, el 23 de marzo, tras la lectura en cabildo de su petición y el consiguiente acuerdo: «obligándose Diego de Vallejo, como principal, y Juan Acacio, como su fiador, por estos dos mil reales, Sevilla por este acuerdo mandó librar» ${ }^{21}$. Ese mismo día, Vallejo y Acacio suscriben la correspondiente escritura de obligación ${ }^{22}$ y se le libran los citados 2.000 reales, como ratifican las anotaciones de las libranzas: tras la de 130.900 maravedís (350 ducados) del 23 de febrero a la firma del contrato, el 23 de marzo figura la de 68.000 mrs. (los 2.000 reales aludidos) y, por último, el 17 de junio se le abonan 62.900 mrs. (1.850 reales), «de resto y a cumplimiento» de los 700 ducados $^{23}$.

Bajo estas condiciones, Diego de Vallejo puso en escena el auto sacramental En los mayores peligros se conoce la amistad, uno de los dos a los que se había comprometido, como ya hemos indicado. Su letra la facilitó el autor de comedias, por lo que no hay duda de que su texto se encontraba en su repertorio, correspondiendo su autoría al dramaturgo José de Valdivielso (Toledo, 1565-Madrid, 1638)24. Un auto denominado también La amistad en el peligro, título con el que figura en las dos ediciones del siglo XVII (1622 y 1624), impresas ambas en vida del escritor ${ }^{25}$. La pieza se ha conservado también en dos manuscritos con letra del siglo XVII ${ }^{26}$ y ha tenido ediciones modernas,

20. Cuadernillo del Corpus de 1679, fol. 207r.

21. Cuadernillo del Corpus de 1619, fol. 207v.

22. Cuadernillo del Corpus de 1619 , fols. 208r-210v.

23. AMS, Sección II, carp. 110, «Data de pagos por los gastos hechos en las representaciones de los carros y otros [...] en las fiestas del Santísimo Sacramento de los años de 1619 y 1620», s. f.

24. Una breve biografía y la referencia bibliográfica de su producción, en Marcello, 2010.

25. La amistad en el peligro. Acto sacramental, en Doze actos / sacramentales, / y dos comedias divinas. / [...] / Por el Maestro loseph de Valdiuielso, Toledo, luan Ruyz, A costa de Martín Vázquez de la Cruz, mercader de libros, 1622, fols. 46r-57r (en adelante, T). Hemos seguido el ejemplar digitalizado de la Biblioteca Histórica de la Universidad Complutense de Madrid (Portales: Universidad Complutense. Fondo Antiguo y Colecciones Singulares. I Fondo Antiguo de Universidades y Colecciones Singulares. Consulta realizada en abril-mayo de 2015). Segunda edición: Braga, Fructuoso Lourenço de Basto, por seu irmão Francisco Fernandez de Basto, 1624, fols. 46r-57r (en adelante, B). Hemos consultado el ejemplar digitalizado de la Library of the University of Toronto. Consulta realizada en abril-mayo de 2015. Para la localización de otros ejemplares de ambas ediciones: Marcello, 2010, p. 567.

26. Biblioteca Nacional de España, ms. 16942, 14 hoj. [portada de época + 13 folios con foliación moderna a lápiz], 4 I. del s. XVII: «A [Cruz] 187 [Numeración tachada] / Avto sacramental fa- / moso Intitulado, la amis- / tad enel peligro compues- / to Por Joseph de Val- / diuiesso, Capellan / Moçaraue» (Marcello, 2010, p. 567, que he comprobado personalmente). E.: Ino. Tanto plaçer, plaçer bello. A.: se conoze el amistad (en adelante, M1). El otro está radicado igualmente en dicha Biblioteca: Mss. 15165, 24 hoj. [portada con letra moderna + 23 folios con foliación moderna a lápiz desde 2 al 24], 4º I. del s. XVII: «Ms. 
si bien a ninguna se le puede atribuir el calificativo de «crítica» $»^{27}$. La más cercana a una edición crítica es la de Arias y Piluso (1975), que reproduce el texto de Toledo (1622) y recoge las variantes de los textos de Braga (1624) y del manuscrito 16942 de BNE. Sin embargo, los mismos editores precisan: «la edición que presentamos no se propone ser una edición crítica, sino más bien una transcripción lo más fiel posible de los textos que se han escogido como base ${ }^{28}$. De aquí, la necesidad de una edición crítica de la pieza a la luz de los criterios de la moderna filología, como ha sido nuestro propósito al enfrentarnos con la obra. Tras el cotejo de los cuatro testimonios antiguos conservados, las variantes registradas han determinado la elección, como texto base, de la edición de Toledo, 1622 (T), reproducida por la de Braga, 1624 (B), con muy escasas variantes no significativas. De ambas, se alejan las copias manuscritas -muy plausiblemente de comediantes-, que presentan numerosas deturpaciones, adiciones y omisiones, siendo más abundantes en el Mss. 15165 (M2) que en el Mss. 16942 (M1), si bien a veces solucionan algún error o errata de la edición base. A lo largo de este trabajo, citaremos siempre el texto por nuestra propia edición ${ }^{29}$.

El auto dramatiza la historia de la salvación del Género Humano por Cristo, a través del recurso de la alegoría, con un propósito aleccionador y de exaltación eucarística. El Hombre, salvado de la primera culpa -el pecado original- por la encarnación del Príncipe como manifiestan Placer e Inocencia, sucumbe de nuevo en ese peregrinar hacia el cielo que es la vida terrena. Tentado por la Culpa con la ayuda de Envidia y Pereza, celosas de los favores concedidos por Dios al Hombre tras su caída, desoye las advertencias de Inocencia y acaba enredado en la maleza -el pecado- como oveja perdida. El Príncipe vuelve a compadecerse de él y le tiende otra vez la mano. El Hombre, arrepentido, Ilora su culpa. Absuelto, el Príncipe lo incita a embarcar en la galera de gracia y a huir del peligro y la desventura. Frente a esta primera galera, que lleva como patrón la Gracia, por piloto un Pastor y por capitán la Iglesia, aparece la galera del deleite, cuyo piloto es el Deseo, su patrón la Mentira y su capitán la Pobreza. Enfrentadas ambas galeras, la mentirosa belleza desde la segunda seduce al Hombre, que cae al agua desde la primera. Vuelve a pedir ayuda al cielo y desde la galera de gracia la Iglesia le arroja una tabla -cruza la que asirse y Nuestra Señora un rosario. Con ambos llega a la orilla, donde le espera el pescador Pedro. El Hombre, arrepentido, pide confesión y, ante la duda de si Dios podrá perdonarlo una vez más, san Pedro le responde que siempre que, contrito, confiese sus pecados. Un Ángel, con un vaso con agua -lágrimas del Hombre arrepentido - y un papel cerrado - carta de Nuestra Señora-, anuncia la llegada de éste ante el Príncipe, acompañado de Penitencia, san Pedro y el Ángel como padrinos. El Hombre se confiesa pecador y se muestra arrepentido. El Príncipe recuerda su pasión y muerte por redimirlo y lo conduce a la mesa celestial. Rigor de Justicia

Incompleto Antiguo / En el mayor peligro se conoce la amistad / Auto» (portada). E.: [Incompleto] Metido en el centro. A.: se conoce el amistad (en adelante, M2)

27. Fue publicado por Eduardo González Pedroso, Autos sacramentales, reimpr.: 1952, pp. 230-244; sin nombre de editor, 1922; Ricardo Arias y Robert V. Piluso, vol. I, 1975, pp. 207-250; Ricardo Arias, 1977, pp. 273-303. 28. Arias y Piluso, 1975, vol. I, pp. 14-15.

29. Al no ser objeto de esta ponencia la edición de la pieza, nos limitamos solo a dar estas ligeras pinceladas sobre los textos antiguos conservados, que se desarrollarán extensamente en su edición. 
y Muerte entran con dos demonios como corchetes y otro como escribano, junto a Envidia y Pereza, en busca del delincuente. Sin embargo, Rigor reconoce que no puede de la Iglesia «los delincuentes sacar» (v. 1397). Absuelto el Hombre por el Príncipe, lo invita a comer en la mesa donde está el maná del cielo - pan y vino- del que fue sombra el veterotestamentario maná.

Como ya hemos indicado, el auto se montó sobre dos medios carros -también denominados simplemente carros-, que se adosaban a una plataforma - plaza de armas - situada en aquellos lugares donde a lo largo de su recorrido se detenían para representar. Los carros, como también se ha dicho, los facilitaba la ciudad a los autores de comedias, bien aderezados y con las tramoyas e invenciones solicitadas por ellos. Sobre la dimensiones de los medios carros y de la plaza de armas, nuestro Cuadernillo no suministra información. Sentaurens, buen conocedor de toda la documentación municipal relativa al Corpus hispalense, precisa que no ha encontrado «ni planos ni descripciones de los carros con sus dimensiones exactas», deduciendo las ofrecidas «de diversos datos diseminados en los contratos y de las medidas de ciertos elementos accesorios montados sobre ellos» $»^{30}$. Siendo éstas las dimensiones más precisas halladas para los carros y dado su interés para nuestro propósito, las reproducimos literalmente, en traducción que nos pertenece:

El carro -escribe Sentaurens - se presenta como una plataforma apoyada sobre cuatro ruedas. Su longitud es aproximadamente de unos $7 \mathrm{~m}$ y su anchura de 2,5 m. Su altura, en relación al nivel del suelo, es de 1,5 m. Su caja, muy sólidamente construida está formada por un suelo cuidadosamente cepillado y un faldón que disimula en parte las ruedas. Estas últimas están unidas dos a dos a dos ejes, uno de ellos orientable, a fin de facilitar las maniobras de la máquina. Cada rueda posee unos radios reforzados y un doble cerco de hierro. La plataforma está rodeada de una pequeña barandilla con balaustres muy bajos, que corre alrededor de las cuatro caras del carro ${ }^{31}$.

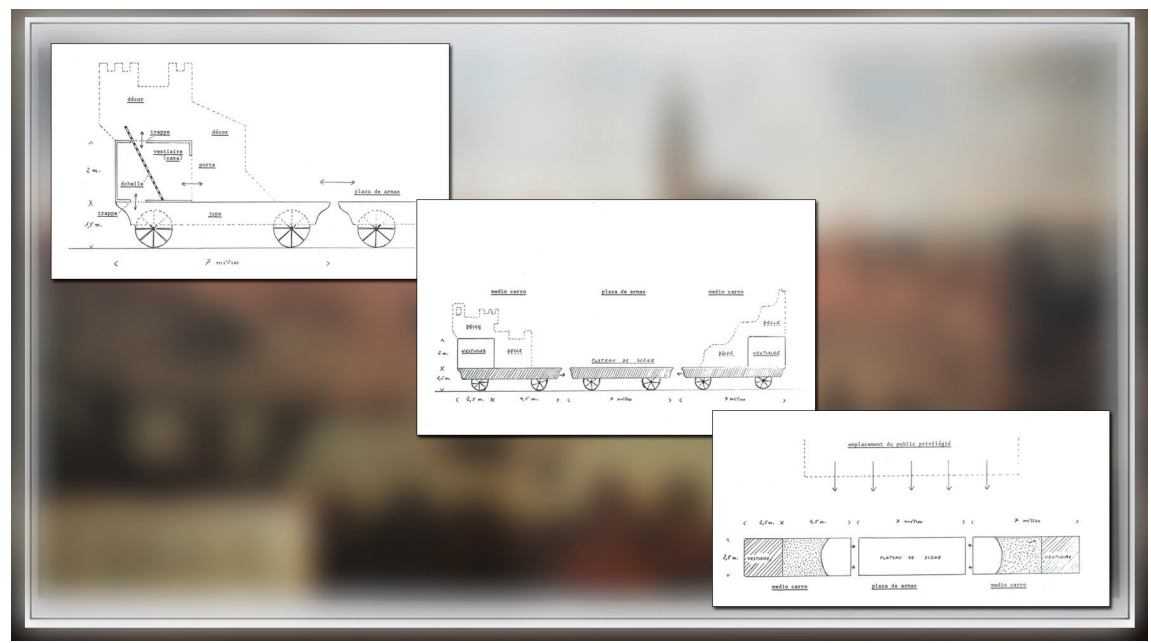

Imagen II

30. Sentaurens, 1984, t. II, p. 888, n. 52 (las traducciones de las citas nos pertenecen).

31. Sentaurens, 1984, t. II, p. 847 (las imágenes en pp. 853, 849 y 848). 
Como punto de referencia, citaremos las dimensiones de los ocho medios carros que Juan de Caramanchel se obliga a hacer para el Corpus madrileño de 1646 en su planta y base de la casilla: la planta había de tener 18 pies de largo $(5,04 \mathrm{~m}) \times 9$ pies de ancho $(2,52 \mathrm{~m})$ y el «basamento» de la casilla (la base sobre la parte posterior de la planta del carro, en cuyo cuerpo alto se colocaban las apariencias facilitadas cada año por los poetas o por los autores) tenía las mismas dimensiones de ancho que la planta $(2,52 \mathrm{~m})$, un largo de 9 pies $(1,68 \mathrm{~m})$ y una altura igual a la de las verjas 0 barandillas, como se aprecia en el dibujo presentado por el citado Caramanche/ ${ }^{32}$. Es

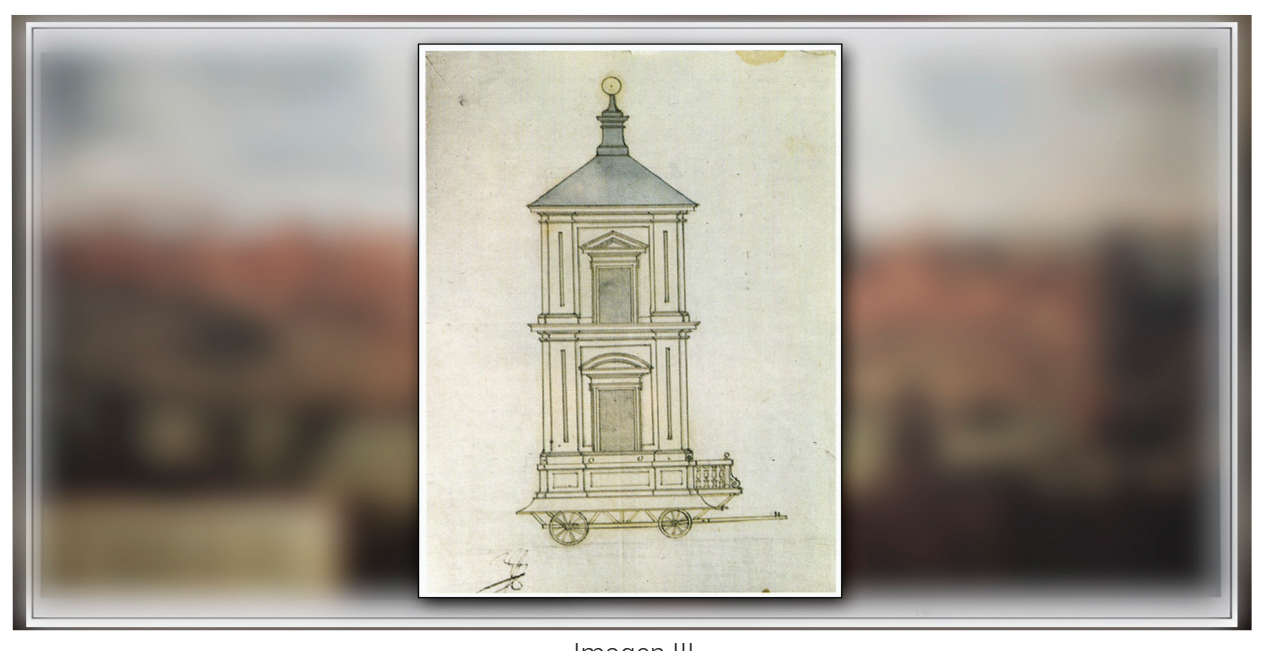

Imagen III

decir, una plataforma de menor longitud que la propuesta para Sevilla por Sentaurens. Aludiendo a referentes reales, las medidas de los pasos de la Semana Santa sevillana poseen unas dimensiones más reducidas, como se aprecia en estos dos ejemplos de «misterio» - los pasos de mayor tamaño entre el conjunto procesional-: Nuestro Padre Jesús del Silencio en el desprecio de Herodes, paso de misterio de la Hermandad de la Amargura, con dimesiones de 5,40 m x 2,30 m x 1,50 m; o La Exaltación de la Hermandad de este nombre (5,70 m de largo; 2,47 m de ancho; 1,67 m de alto de la parihuela; y 0,70 m alto de la canastilla.

Sobre esas plataformas - una correspondiente a cada medio carro- el maestro carpintero debía «hacer las invenciones de los autos, y las casas y tramoyas [...]», de acuerdo con las condiciones indicadas en nuestro caso por los respectivos autores de comedias:

Primeramente, es condición que el dicho maestro ha de hacer para los dichos sinco autos [los representados este año de 1619] diez casas [dos para cada uno] con sus bastidores, puertas, esquinas y escudos, cornijas, capiteles, pirámides

32. Shergold y Varey, 1961, pp. 64-65, doc. núm. 66. Reproducimos la imagen por Bernáldez Montalvo, 1983, p. 16. 


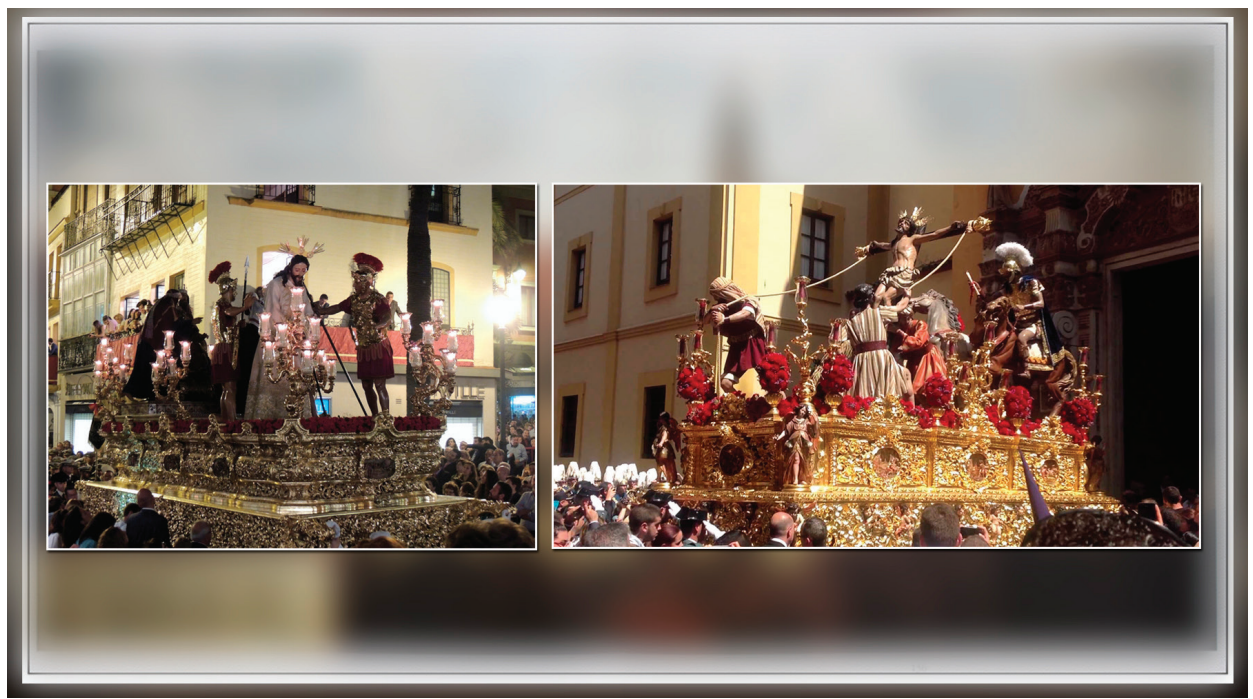

Imagen IV

que hubieren menester, acomodando las invenciones para cada car[r]o, como aquí irá declarado en particular, acomodando a cada auto lo que le tocare ${ }^{33}$.

A las «casas», con forma de paralepípedo rectangular que servían a los actores de vestuario y de bastidores, en un documento del Corpus de 1639 se le atribuyen estas medidas:

Primeramente es condisión que la persona que de esto se encargare ha de ser obligado a armar las ocho casas que sirven de vistuarios de tres varas menos cuarta de largo [2,69 m], con sus testeros del ancho de las plasas en la forma ordinaria, y dos varas y tersia de alto [1,93 m] con sus formas de cornisas en sus bastidores fuertes, de su tabla enterisa, con sus guarniciones en las esquinas y sus tarjas en los encornisamentos, poniendo sus almas de pinetes enteros con sus telares, sobre que se han de armar las tramoyas, clavándolos y asigurándolos con toda fortaleza en las cajas de los carros, enlensando todos estos bastidores como es uso y costumbre de su lienso delgado fuerte para que pueda resebir la pintura ${ }^{34}$.

Sentaurens les atribuye unas medidas de 2,5 $\mathrm{m}$ de largo x 2,5 $\mathrm{m}$ de ancho $\mathrm{x}$ $2 \mathrm{~m}$ de altura sobre el nivel de la plataforma del medio carro ${ }^{35}$. La colocación del

33. «Las condiciones que ha de guardar el maestro carpintero que se encargare de hacer las invenciones de los autos, y las casas y tramoyas y los demás ingenios que fueren menester en los sinco autos de representación que se han de hacer para el día del Sacramento, que es a 30 de mayo de 1619», Cuadernillo del Corpus de 1679, fols. 256r-258v, la cita en fol. 256r

34. AMS, Sección IV, t. 11, doc. 44, «Memoria y condisiones que se han de guardar en la fábrica de las casas y apariensias que se han de haser en los ocho carros triunfales para la festividad de la fiesta del Corpus, que su declarasión es del tenor siguiente», 3 de mayo de 1639 (fol. 258r-v, la cita en fol. 258r). De estas dimensiones ya daba cuenta Sánchez-Arjona, El teatro en Sevilla en los siglos XVI y XVII (Estudios históricos), pp. 63-64.

35. Sentaurens, 1984, t. II, pp. 851-853. Sobre la forma de fabricación de estas casas, sus materiales constructivos y su distribución, ver Sentaurens, pp. 852-855. A este propósito, es también revelador par- 


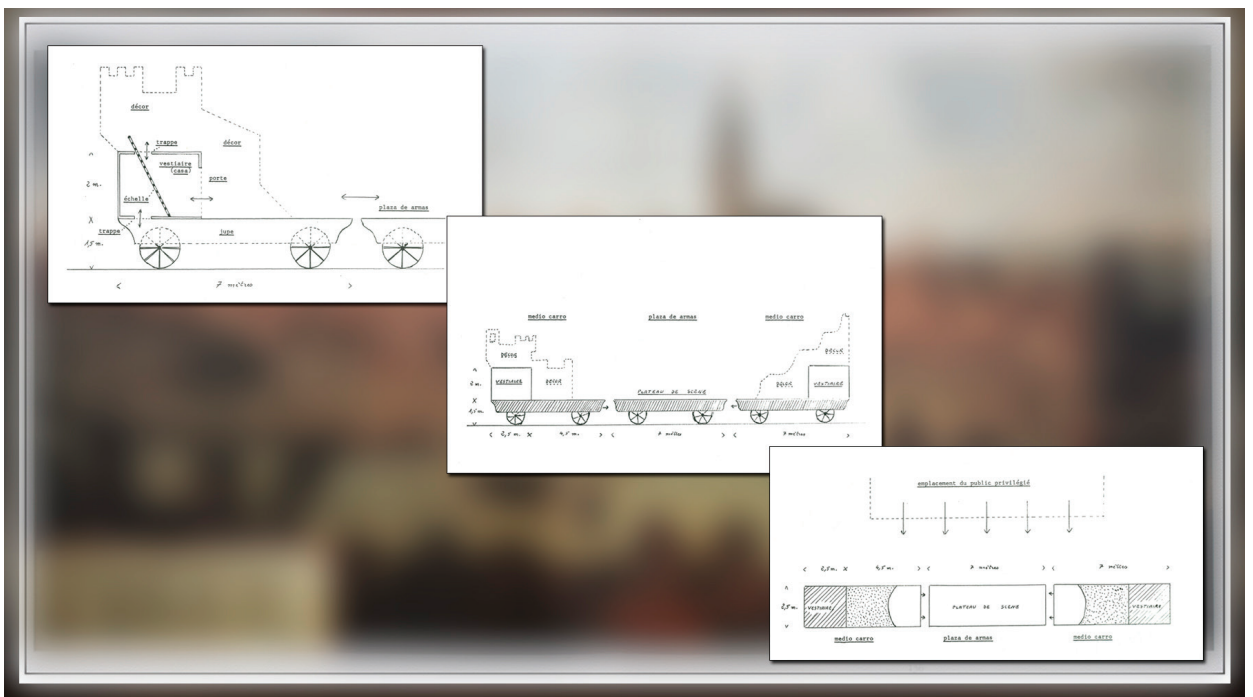

Imagen II

decorado sobre ella elevaba notablemente la altura que alcanzaría el carro sobre el nivel del suelo de la calle. Recordemos como ilustración el dibujo de Caramanchel ya referido para los carros del Corpus madrileño de 1646; o los conocidos versos de Calderón de la Barca pertenecientes a la loa para el auto La segunda esposa y triunfar muriendo, que debió de representarse en el Corpus madrileño de $1649^{36}$ o 164837, donde la Labradora que interviene en ella se refiere a los carros como «aquellas torres, / o triunfales carros, que / el aire ocupan disformes» (vv. 154-156); o la recreación hecha por Varey para el auto de La adúltera perdonada de Lope de Vega, en su representación madrileña de 1608.

\section{Las condiciones del auto En los mayores peligros se conoce la amistad, rezan así:}

Ytem que sobre las casas ya dichas ha de hacer dos galeras de buen tamaño y proporsión, la una con las jarcias negras y la otra de gloria con las jarcias de muchas colores, las cuales se han de mover a la redonda, de modo que se encuentren y ha de hacer un monte donde lo pidieren los autores ${ }^{38}$.

te del contrato para la decoración de los carros del Corpus de 1641, publicado por el citado estudioso: «Primeramente, es condición que ha de ser obligado -el carpintero- a armar las ocho casas que sirven de vestuarios de tres varas menos cuarta de largo [2,11 m], con sus testeros, y de dos varas y tercia de alto [1,79 m], en la forma ordinaria, con sus bastidores fuertes, de sus tablas enterisas, con sus formas de cornisas, con sus guarniciones en las esquinas y sus tarjas en los encornizamientos, enlensando estos bastidores de su lienso nuevo, delgado y fuerte, para que puedan recebir la pintura, no aprovechando lienso viejo; y si se ofreciere ser menester alargar algunas de estas casas más que lo ordinario y que convenga para las representaciones, tenga obligación de hacerlas...» (Sentaurens, 1984, t. II, p. 854). 36. Ver Alexander A. Parker, 1983, p. 236.

37. Sobre el problema de la fecha de este auto ofrece un breve resumen José María Díez Borque, 1984, p. 122, ed. por la que citamos.

38. Cuadernillo del Corpus de 1679, fol. 257r, publicadas por Sánchez-Arjona (Noticias referentes a los anales del teatro en Sevilla desde Lope de Rueda hasta fines del siglo XVII, p. 207) y Sentaurens (1984, 


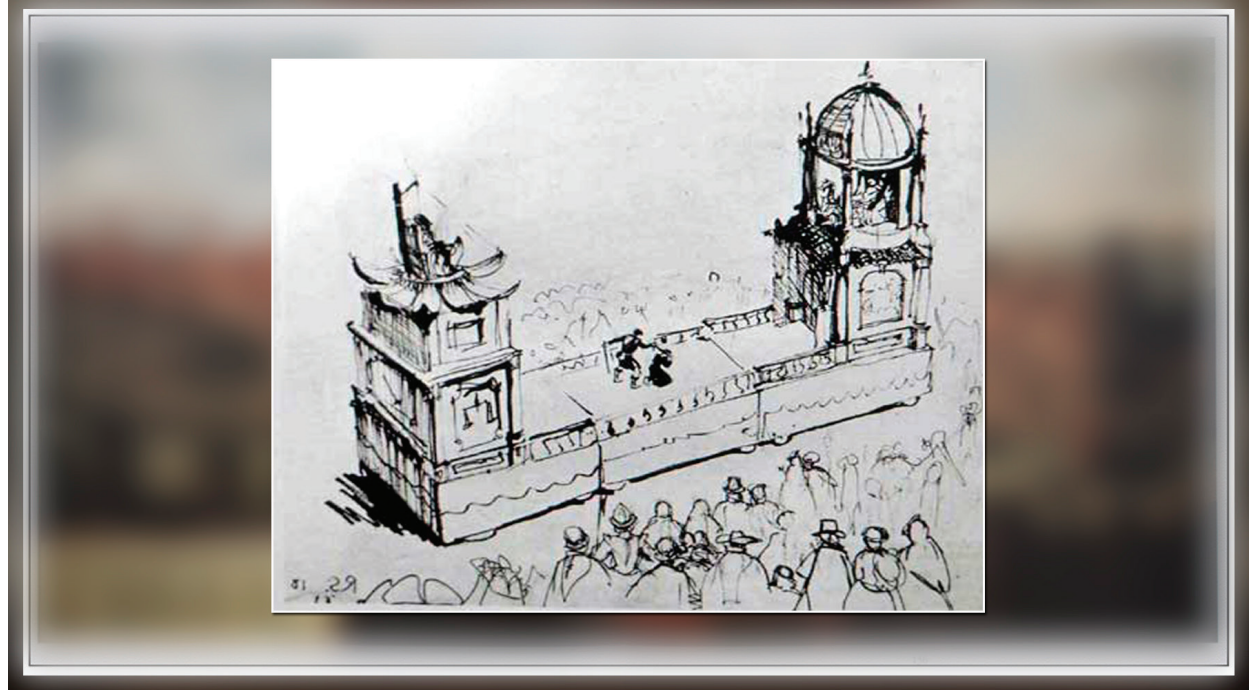

Imagen V

Efectivamente, la letra del auto demanda estas dos galeras, que a través de un detallado decorado verbal se describen - primero la de gloria (o gracia) y después la infernal-con todo lujo de detalles, como muestran sus respectivos versos, puestos en boca de Envidia y Pereza respectivamente (vv. 913-963 y 965-1012):

\begin{tabular}{|c|c|}
\hline INVIDIA & $\begin{array}{l}\text { Al turbado mar del mundo, } \\
\text { vuelve los ojos, Pereza, } \\
\text { verás que el Hombre se embarca } \\
\text { en la fletada galera. } \\
\text { Lleva por patrón la Gracia, } \\
\text { por piloto un Pastor lleva, } \\
\text { y en la cámara de popa } \\
\text { por su capitán la Iglesia. } \\
\text { Son los doce de la boca } \\
\text { guzmanes que la defiendan } \\
\text { de solas lenguas armados, } \\
\text { que son sus armas las lenguas }{ }^{39} \text {. } \\
\text { Mártires son los soldados, } \\
\text { todos con armas diversas, } \\
\text { garfios, navajas, parrillas, } \\
\text { aspas, dardos, fuegos, flechas. } \\
\text { Los remeros son doctores, } \\
\text { que uniformemente reman } \\
\text { en vez de remos con plumas, } \\
\text { con gue más aue el viento vuelan }\end{array}$ \\
\hline
\end{tabular}

39. vv. 921-924: es decir, 'los doce de la embocadura de la galera son nobles soldados, con distinción, que la defienden con su palabra', alusión alegórica a los doce apóstoles de Cristo, que predicaron y difundieron su doctrina. 
Para su seguridad,

lleva reforzadas piezas;

por pólvora, furor justo,

por balas, divinas letras.

Por árbol, el de la vida,

donde fue la vida muerta;

por jarcias lleva rosarios,

cintas, cordones, correas.

De los ángeles las alas

le van sirviendo de velas,

en cuyos senos aspira

con su aliento el Sacro Neuma ${ }^{40}$.

En la gavia aquella Virgen,

cuyo nombre es bien que tema,

que antes del parto y en él

y después dél fue doncella.

Los grumetes son meninos

que acompañan la Inocencia,

que, a mi pesar y al de Herodes,

hasta el mismo cielo trepan.

va por lastre la humildad,

a quien sigue la paciencia,

es la verdad la crujía,

cómitre ${ }^{41}$ la diligencia.

No que ejercita el rebenque ${ }^{42}$,

que nadie forzado rema,

mas porque, experimentado,

a los bisoños ${ }^{43}$ ordena.

Lleva por matalotaje ${ }^{44}$

pan, bizcocho y carne fresca,

todo del que desde el cielo

vino a ser lo que no era ${ }^{45}$

PEREZA En otra galera, mira,

de coral, nácar y perlas,

por velas vanas espumas,

desnuda la Venus bella;

niños amores remando,

en vez de remos, con flechas,

con que las ondas abrasan

y con que los aires yelan.

40. Sacro Neuma: 'el Espíritu Santo'.

41. cómitre: «Persona que en las galeras vigilaba y dirigía la boga y otras maniobras y a cuyo cargo estaba el castigo de remeros y forzados» (DRAE, s. v.).

42. rebenque: «látigo, hecho de cuero u de cáñamo, de dos varas de largo, poco más o menos, y embreado, al cual se le pone su mango, y sirve para el castigo de los galeotes cuando están en la faena» (Aut., s. v.).

43. los bisoños: 'los galeotes nuevos'.

44. matalotaje: 'prevención de comida que se lleva en una embarcación' (DRAE, s. v.).

45. vv. 963-964: 'Cristo', es decir, la segunda persona de la Santísima Trinidad encarnada como hombre. 
Mira a Cupido a su lado,

que lazos tira y saetas,

desnudo, porque desnuda,

cieguezuelo, porque ciega.

Tras la hermosura gozada,

valloroso, a la ligera,

el triste arrepentimiento,

que siempre viene tras ella.

El deseo es el piloto,

que el timón rige y gobierna;

su patrón es la mentira;

su capitán, la pobreza.

Son los soldados pesares,

celos, desdenes, sospechas,

dolores, quejas, desvelos,

lágrimas, iras, dolencias.

Mira, Invidia, que por lastre

van corazones de piedra,

que ya por su obstinación

mudaron naturaleza.

El árbol es el de Adán,

con manzanas y culebra;

por jarcias, telas de araña,

porque así son sus promesas.

La muerte viene en la gavia,

que, harta siempre y siempre hambrienta,

descubre tierra sin ojos

y da voces: «iTierra, tierra!»

En la cámara de popa,

porque el Hombre no le vea,

va el infierno, que es el postre

deste hechizo y hechicera.

Son los grumetes amantes

que, por escalas sin cuerdas,

rotos, subiendo y bajando,

no alcanzan lo que desean.

A la galera de gracia,

que viento en popa navega,

la galera del deleite

quiere acometer ligera.

Sin embargo, a pesar de que la acotación explicita inmediata a estos versos indica «Aparecen las dos galeras lo más conformes al romance que pudieren» (v. 1012 acot.), al carpintero solo se le encargan dos galeras de «buen tamaño y proporsión» con sus respectivas jarcias diferenciadoras: negras para la galera infernal y de muchos colores para la galera de gloria. El hecho de que se preparen, por una parte, la plataforma de los carros y, por otra, se contraten las invenciones, las casas y tramoyas de los autos, así como la tradición de la utilización sobre ellos de naves, 
permite pensar que no se trataba de naves-carros, sino de carros portando naves en su parte superior ${ }^{46}$.

La adjetivación sobre cómo debían ser las galeras inclina a pensar que ocuparían la mayor parte de la plataforma de los medios carros que las sustentaban, ratificando los esquemáticos dibujos de Sentaurens, cuando visualiza los carros y su anexión a la plaza de armas ${ }^{47}$. La precaridad de estas «memorias de aparien-

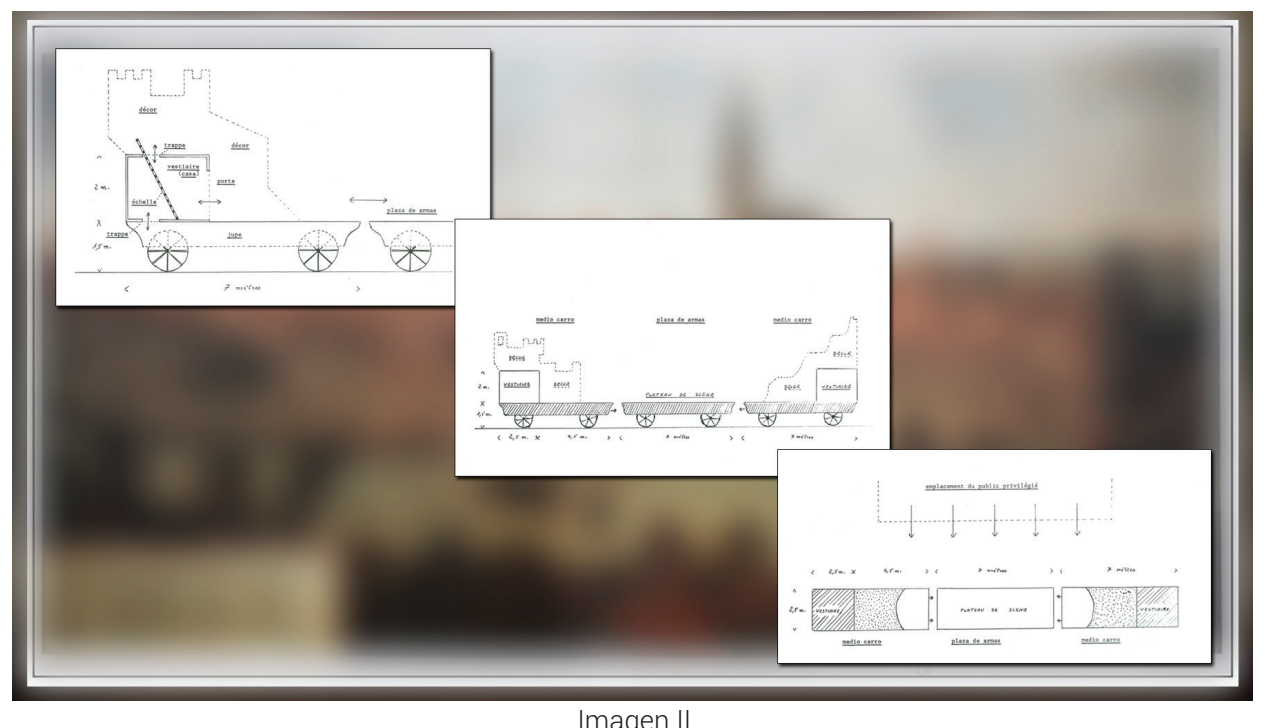

cias» a la hora de imaginarse las galeras quizá pueda solventarse en algo con las conservadas de otros años del primer cuarto de siglo. Así, en 1609, en el auto de La Ionja, representado por Nicolás de los Ríos, se requiere:

Y en el otro medio carro a de aver una caja [casa] que se finja la lonja y sobre ella un navío con todas sus jarcias y en el mástil del medio a de aver una nave que a su tiempo se abra una nube que a de aver en la dicha nabe donde ha de aparecer el Smo. la sagrada forma ${ }^{48}$.

Y ese mismo año en otro auto representado por el mismo autor, La nave mercenaria, se estipula:

En el un medio carro a de aver un castillo pintado de gloria tras del cual a de aver un navío al natural con sus flámulas y gallardetes de tafetán de colores, pintados en ellas los ynstrumentos de la pasión de Cristo.

46. Para la representación de naves en escena, ver el ilustrativo epígrafe «Barcos», en Eva Rodríguez García, 2014, pp. 229-241.

47. Sentaurens, 1984, t. II, pp. 848-849.

48. Sánchez-Arjona, El teatro en Sevilla en los siglos XVI y XVII (Estudios históricos), p. 300. 
item, además una + [cruz] con una invención que a su tiempo salga una ostia de la grandeza de un estado de un hombre dentro del dicho navío y forma de tramoya, por quel navio a de bolverse a su tiempo ${ }^{49}$.

En fecha posterior, 1623, cercana al nuestro -cuatro años después-, para el auto El valle de la muerte, de Andrés de Claramonte, representado por Tomás Fernández, las memorias de apariencias y tramoyas indican:

En lo alto de una casa se ha de rematar con una nave capaz para seis hombres que parezca el arca de Noé, y a de poder moverse a todas partes y a de tener escalera por donde se suba y se represente por de dentro y de fuera de la dicha nao, y a de estar muy bien pintada ${ }^{50}$.

Por último, resulta significativo respecto a la variedad y multiplicidad del decorado que podían portar los carros este pasaje de la «Memoria y condisiones que se han de guardar en la fábrica de las casas y apariensias que se han de haser en los ocho carros triunfales del Corpus de 1639»:

Y es condisión que haya de haser -el carpintero-, y sea obligado, todas las tramoyas que fueren menester en los dichos carros, así de montes como de torres, nubes, hojas, y globos, y tronos, sierpes, caballos, y ág[u]ilas, y dragones, y elevasiones, y cortinas, escaleras, y altares, corderos, y calises, y tornos, y tiseras, y de bofetón, y todo demás que fuere menester conforme la memoria que dieren los abtores, todo vestido y fuerte a satisfasión de los dichos abtores y guardarropas ${ }^{51}$.

Es plausible que nuestras galeras quizá hubieran tenido más ornato que el exigido en las «Memorias», pero, desde luego, es casi imposible que reflejaran fielmente el espacio dramático configurado en la mente del espectador mediante la palabra. Respecto al término Aparecen, que sugiere una mostración inesperada y sorpresiva, el tamaño que tendrían las citadas naves para dar impresión de verosimilitud en relación con las dimensiones de los carros y de los actores, hace poco probable que durante su recorrido por la urbe estuvieran cubiertas - por una enramada, por ejemplo- y que se dejarán ver ya tan avanzado el auto, por lo que nos inclinamos por la opción de que estuvieran a la vista durante toda la representación.

Aunque nada se especfica en la documentación sobre las pinturas que adornaban las superficies anterior, posterior y laterales de las casas instaladas sobre los medios carros de nuestro auto ${ }^{52}$, se sabe que iban pintadas con motivos alusivos a las historias representadas, como ponen de relieve otras memorias de la pintura. Valgan como ejemplo las de los medios carros del auto de El valle de la muerte (1623) arriba citado:

49. Sánchez-Arjona, El teatro en Sevilla en los siglos XVI y XVII (Estudios históricos), pp. 304-305.

50. Sentaurens, 1984, t. II, p. 1150.

51. AMS, Sección IV, t. 11, doc. 44, «Memoria y condisiones que se han de guardar en la fábrica de las casas y apariensias que se han de haser en los ocho carros triunfales para la festividad de la fiesta del Corpus, que su declarasión es del tenor siguiente», 3 de mayo de 1639 (fol. 258r-v, la cita en fol. 258r). 52. En las «Condiciones de las invenciones, casas y tramoyas [...]», solo se precisan las pinturas de los carros El príncipe de la Luz (Cuadernillo del Corpus de 1619, fol. 256v), La ninfa del cielo (fol. 257r) y La serrana de Plasencia (fol. 257v), sin que en ninguno de los dos carros sacados por Vallejo se estipule nada al efecto. 
A de pintarse una varca entre las aguas con ombres en ella y sobre las aguas un ombre y una mujer danzando en un lado; en otro lado, la torre de babilonia y en lo alto un ángel derribando un gigante; en otro lado Jacobo en ávito de pastor con una pastora de la mano y una portuguesa danzando y otros portugueses bien pintados; en otro lado la muerte bizarra en un carro triunfal tirando dél Adán coronada la cabeza de la muerte con cadenas y el pecado delante y muchos diablos cantando; en otro lado el arca del testamento en unas andas como en procesión y el Rey David baylando delante e gitanas baylando; en otro lado a Cristo glorioso en figura de salvador y a los pies la muerte fea y el pecado ${ }^{53}$.

O bien estas otras de índole general para la pintura de los cuatro carros (ocho medios carros) de 1642:

Primeramente, es condición que el maestro pintor que de estos carros se encargare a de ser obligado a aparejar los treinta y dos lienzos de las casas bajas que sirven de vestuarios y en los dieciséis grandes [los laterales] ha de pintar las historias que contienen los autos, de colores finos, vestidas las figuras con todo el adorno que ser pueda, imitando al natural, así en esta parte como en los edificios y en su perspectiva como en los países, jardines, lejos y celajes, que todo tenga perfección; y en los dies y seis liensos de los testeros [posteriores y anteriores], en los ocho de ellos [posteriores] se han de pintar sus tarjas con las armas de la Ciudad, abronsadas y sombreadas, y en los otro ocho liensos [anteriores], ha de pintar sus portadas de sus compartimentos, de diferentes colores, con sus encornisamientos, todos los lienzos con sus tarjas y guarniciones de columnas y pilastras de forma que estén acabadas estas ocho casas en toda perfección ${ }^{54}$.

Escenográficamente, la documentación para nuestro auto también demanda un «monte» al carpintero, sin precisar dónde iría erigido, dejándolo a voluntad del autor. Cuesta trabajo imaginar dónde se hallaría, en el caso de que estuviese figurado en el espacio escénico, pues éste era muy limitado para su colocación en la parte delantera de los medios carros libre de decorados. Tampoco la plaza de armas parece lugar adecuado, pues, dedicada al movimiento de los actores ${ }^{55}$, se encontraba ya instalada cuando aquéllos se adosaban a ella. Además, el texto de las acotaciones sugiere que debía levantarse precisamente sobre uno de los dos medios carros. No hay duda de que las acotaciones exigen «un alto» en dos ocasiones: a) Inocencia «Sale a lo alto» (v. 731 acot.), posición ratificada por el verso «en alto me veo» (v. 735); y b) «Pereza y Invidia por lo alto» (v. 900 acot.). No obstante, es posible que estos «altos» no aludieran a un monte, sino a un nivel superior, elevado respecto al plano del suelo de la plataforma del carro pisada por los actores.

Las necesidades de decorado que en cierto momento requiere la acotación «Sale el Hombre mojado, asido a la cruz, al cuello un rosario, tendido sobre el teatro» (v. 1104 acot.), las resuelve Rodríguez García con el recurso a una tabla -la cruz- con ruedas, asida a la cual el Hombre se desliza sobre el escenario, precisando que «las tablas se moverían gracias a un hilo del que tiraría otra persona (dentro o fuera de la vista)» ${ }^{56}$. 
Hasta aquí la escenografía demandada por el auto y la documentación conservada. Ésta se vería enriquecida y dinamizada con el concurso del vestuario, la palabra, la gestualidad, el movimiento de los actores, la utilería del decorado y de los personajes, y la música, como ponen de relieve las acotaciones explicitas e implícitas de la pieza.

A la hora de la reconstrucción virtual de los dos medios carros del auto En los mayores peligros se conoce la amistad, la casi total carencia iconográfíca de la época al respecto y la falta de más abundantes datos documentales y literarios dificultan su levantamiento. Quizá pueda sorprender esa carencia iconográfica a la que aludimos, si se recuerdan los espectaculares carros triunfales que el testimonio de los grabados y pinturas ha visualizado para la posteridad (Imágenes VI, VII, VIII, IX y X), pero no ha quedado memoria gráfica, al menos, para Sevilla, de los también espectaculares, pero más rudimentarios, carros de Corpus.

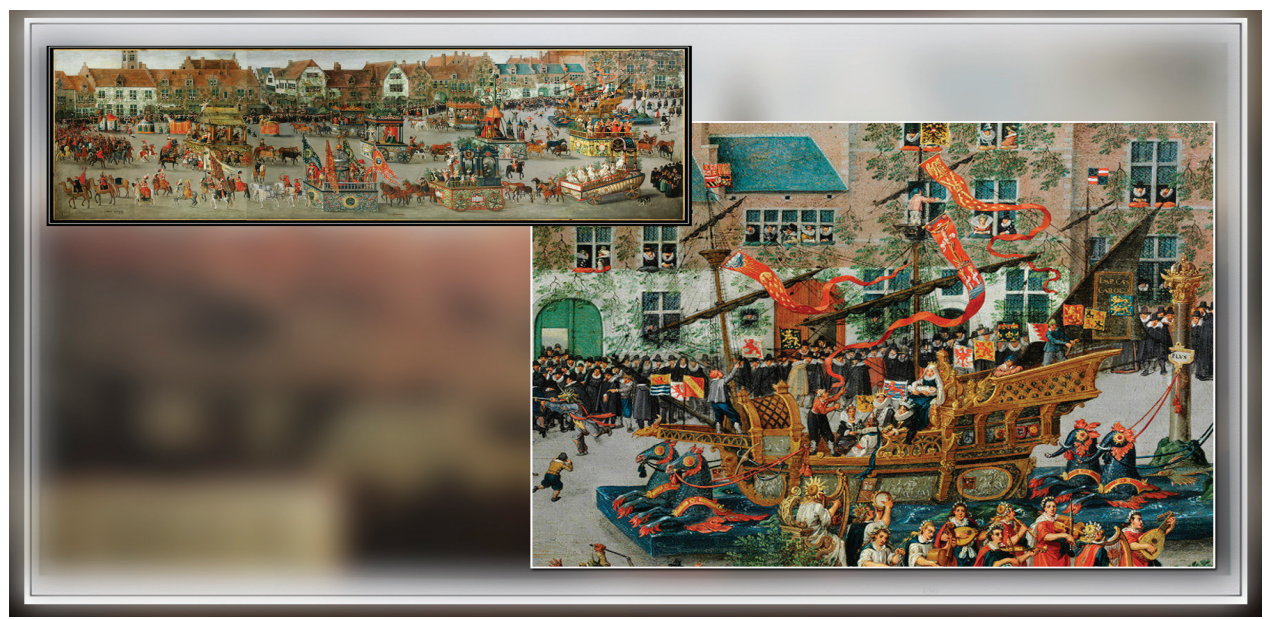

Imagen VI

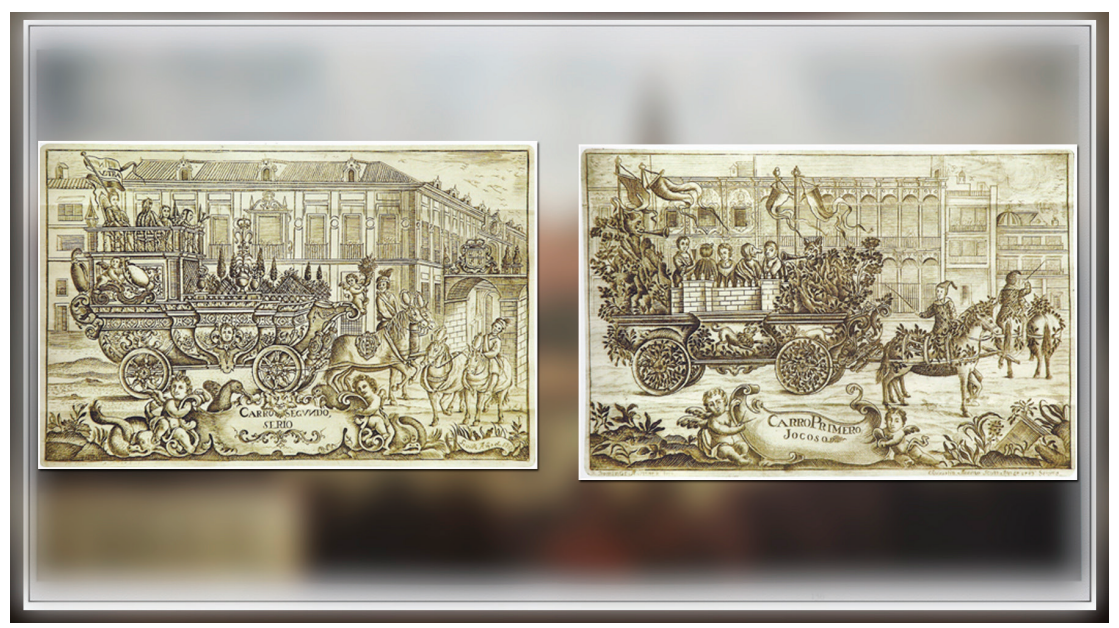

Imagen VII 


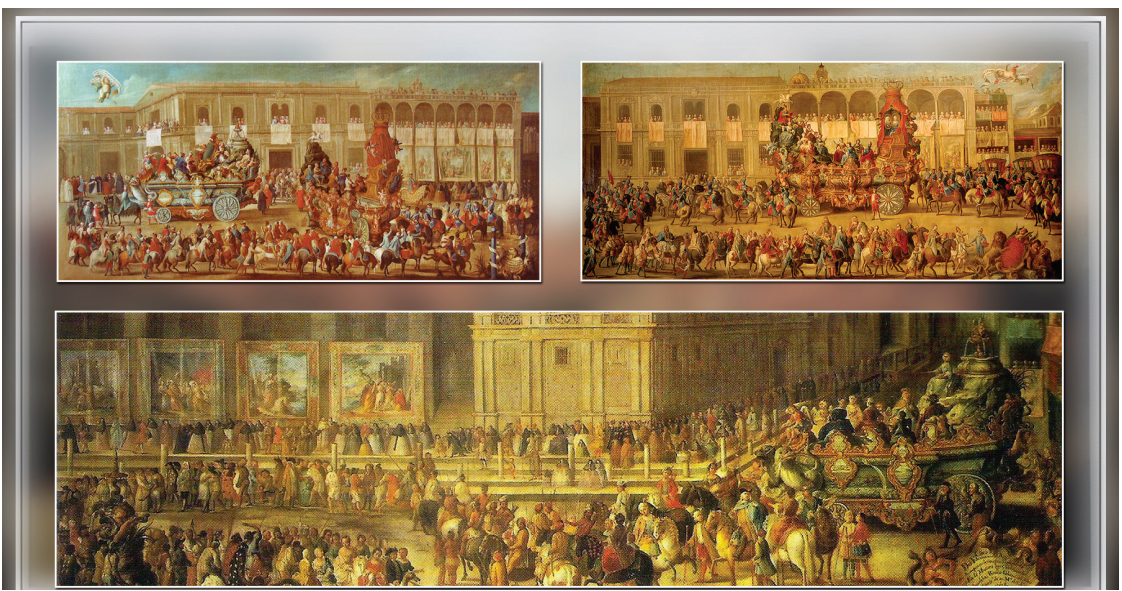

Imagen VIII

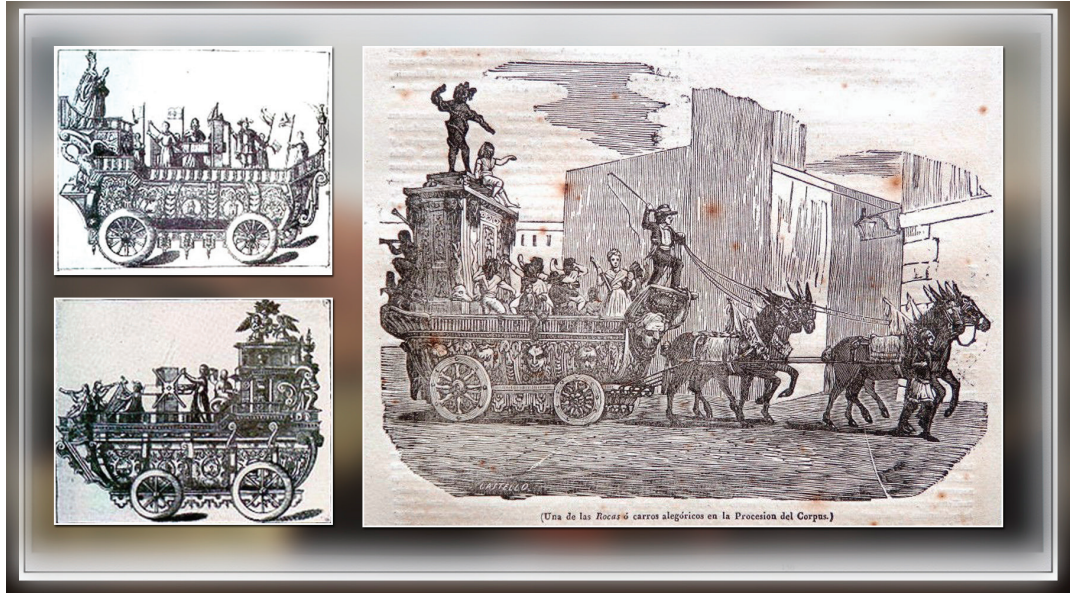

Imagen IX

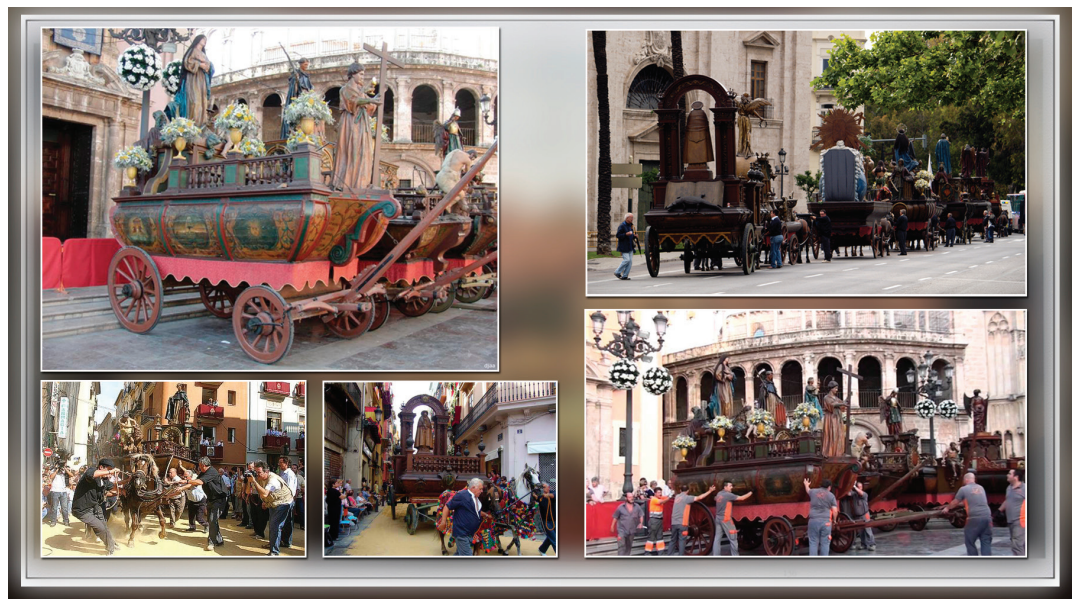

Imagen $X$

HIPOGRIFO, 5.2, 2017 (pp. 11-42) 
Tras este acopio documental e informativo imprescindible para nuestro propósito, con los recursos a nuestro alcance y con todas las reservas posibles, nos dispusimos a la reconstrucción virtual de esos dos carros del Corpus de 1619. Conviene advertir que la reconstrucción virtual de un objeto del que solo conocemos datos bastantes generales implica un alto compromiso hipotético por cuanto su visualización exige formas, medidas y proporciones, texturas y colores concretos, así como la incidencia sobre ellos de la luz, sombras arrojadas, etc., si se pretende conseguir una cierta verosimilitud. Sin embargo, nuestro compromiso y determinación nos animaron a intentarlo.

En este proceso, nuestra atención se centró en primer lugar en el soporte de la estructura sobre la que se instalarían el resto de los elementos para la representación: el carro que los comediantes recibían, como hemos visto, de la municipalidad. Debería tratarse de un artefacto resistente, consolidadas sus características y tamaño tras años de experimentación y superación de dificultades. Aun así, es mucha la insistencia en los requerimientos de las condiciones y contratos en la prevención de accidentes, lo que nos obliga a pensar que seguían produciéndose con frecuencia. Consistirían, como también hemos visto, en una estructura rectangular con cuatro ruedas montadas sobre dos ejes, el delantero orientable, con las ruedas más pequeñas para permitir el mayor giro posible. Ruedas bien armadas y reforzadas de hierro para resistir el peso y los cerrados giros a los que se sometería por las angostas -y de suelo irregular - calles del trazado urbano.

Precisamente, los carros destinados al transporte de mercancías pesadas poseían estas características, en particular, el denominado «galera». Se trataba de un vehículo destinado a las labores agrícolas y el acarreo de grandes pesos como el aceite, que después también se emplearía para el transporte de personas. Ésta nos pareció una buena referencia como la estructura básica que el municipio ofrecía a los comediantes. Sobre sus medidas, hemos visto que existen pocos y diversos

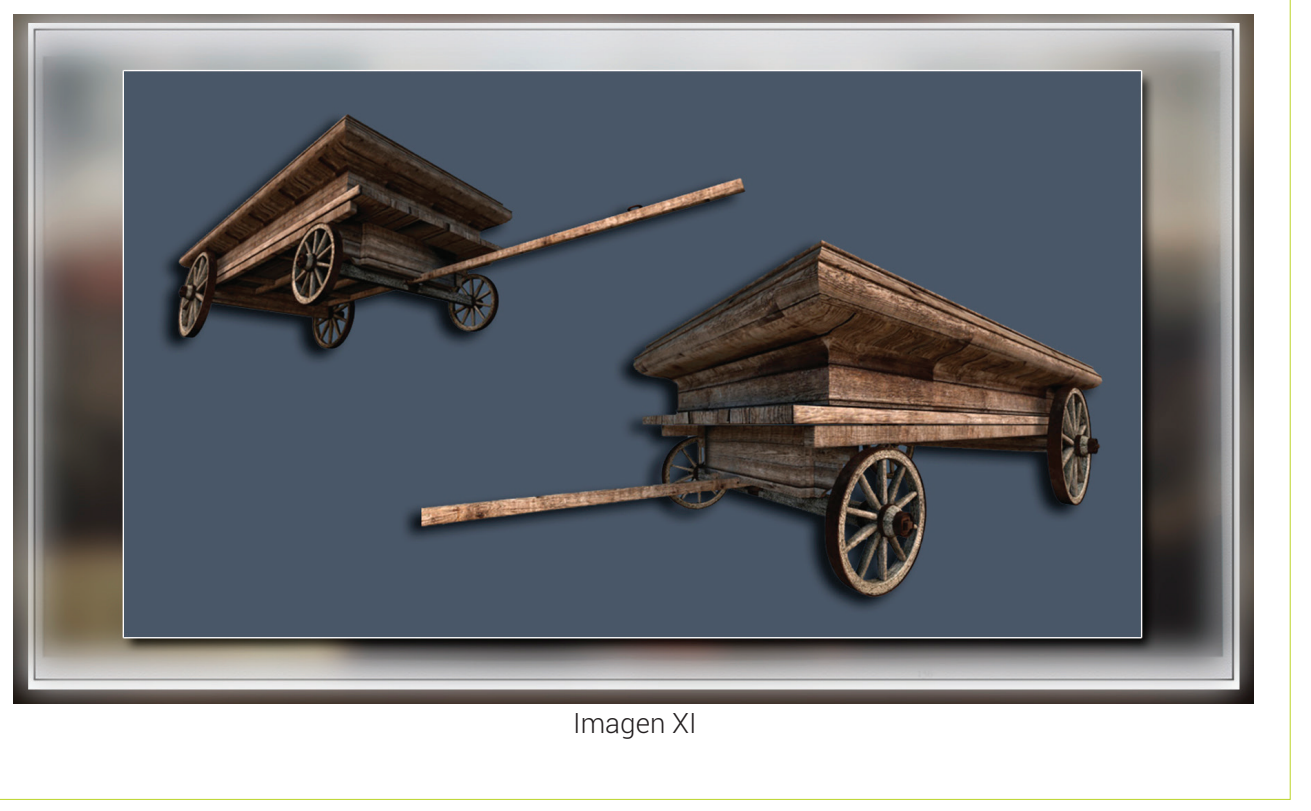

HIPOGRIFO, 5.2, 2017 (pp. 11-42) 
datos, pero hay uno ineludible: debían de poder recorrer el trazado urbano por el que año tras año discurría la procesión del Corpus, en particular los giros de noventa grados en calles estrechas y llenas de gente, como veremos más adelante.

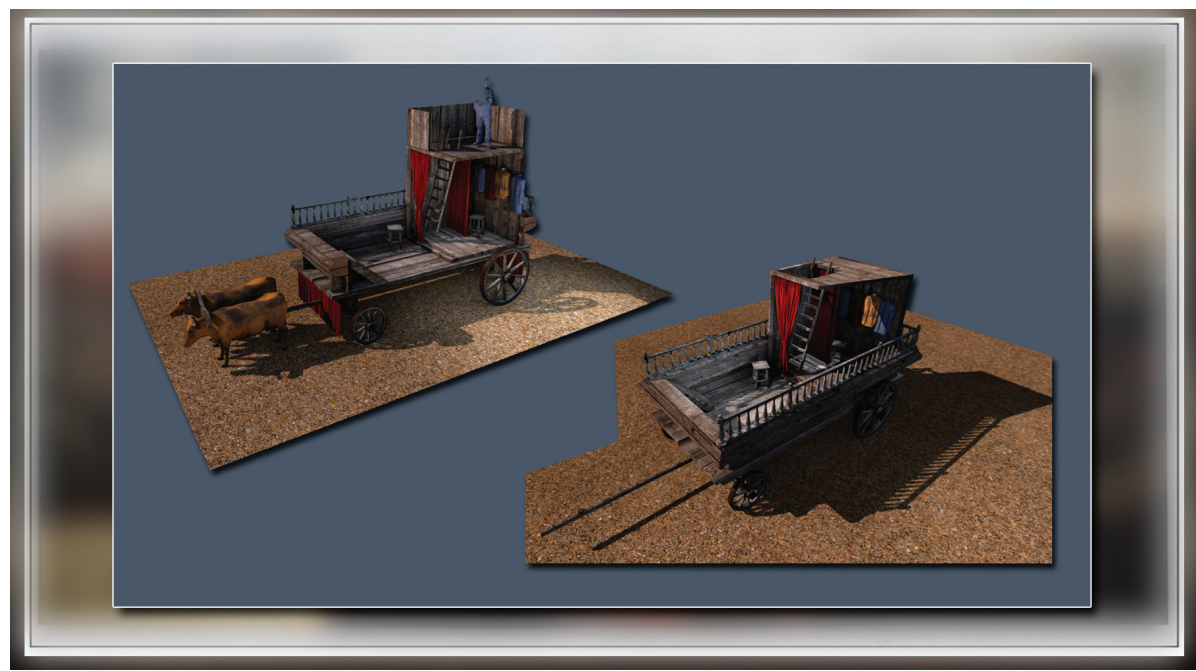

Imagen XII

Sobre esta estructura se instalaría la denominada «casa», un paralepípedo de unos dos metros y medio cuadrados que serviría de vestuario y para alojar los mecanismos de las tramoyas. El conjunto de esta estructura sería el soporte para el resto de los elementos escenográficos. En definitiva, un carro con un habitáculo encima que cubría dos funciones primordiales: servir de vestuario a los comediantes y alojar los necesarios dispositivos técnicos para mover las tramoyas. Esto con-

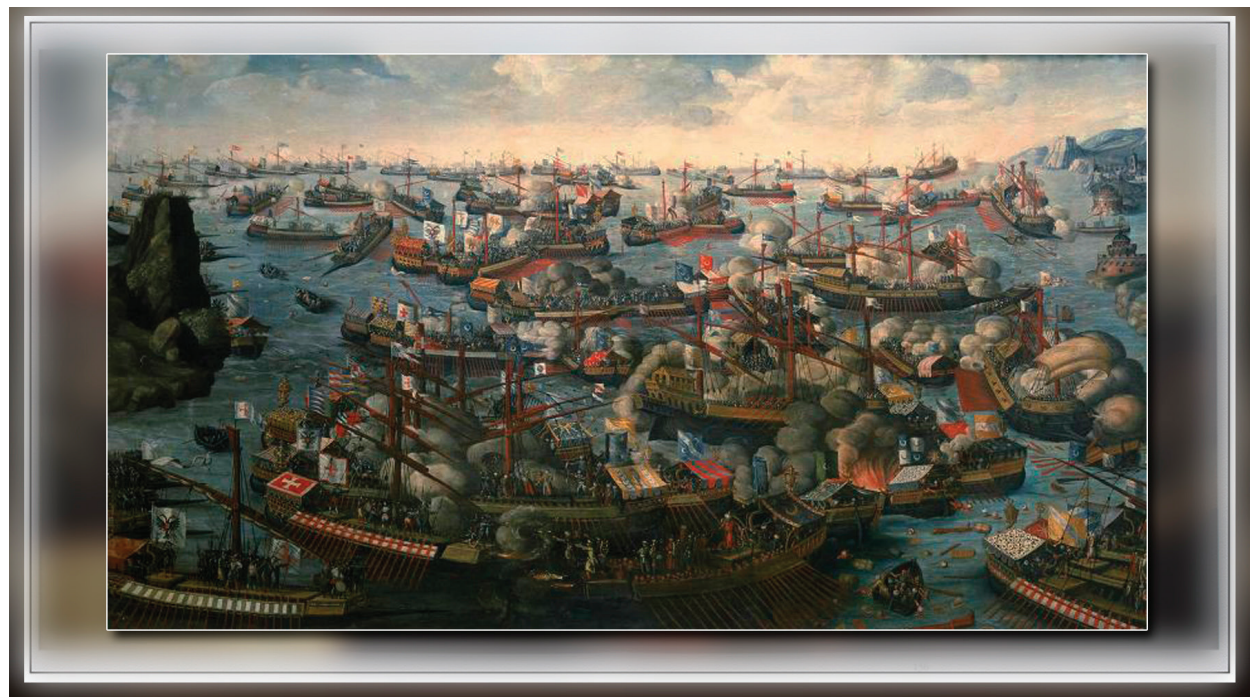

Imagen XIII 
vertía al dispositivo en un auténtico teatrito ambulante. Es conocido también que podía disponer de algún escotillón para acceder a él desde el exterior, así como de alguna escalera que facilitaría la subida a su parte superior. Aun sin decorar exteriormente, podemos apreciar que se trata de un artilugio muy imaginativo y versátil.

Sobre esta «casa», o en torno a ella envolviéndola, se construirían las variadas decoraciones exigidas por el autor. En el caso que nos ocupa, el autor describe: «dos galeras de buen tamaño y proporsión, la una con las jarcias negras y la otra de gloria con las jarcias de muchas colores» -recordemos-. La galera -el barco en este caso-, como es conocido, era el buque capital de la marina mediterránea, vinculada inevitablemente a la batalla de Lepanto (1571) y protagonista de todo tipo de episodios tanto reales como pictóricos o literarios. Sin duda, el dramaturgo la elige acertadamente como metáfora para el enfrentamiento entre el bien y el mal.

En cuanto a su tamaño, nos hemos decantado por construir un elemento que atienda tanto a la expresión «de buen tamaño y proporción» como a lo descrito en el romance del auto, optando por la solución ofrecida en las imágenes. El resultado es una nave, evidentemente no a escala real, pero si practicable para atender las exigencias de la representación: «de buen tamaño y proporción», insistimos.

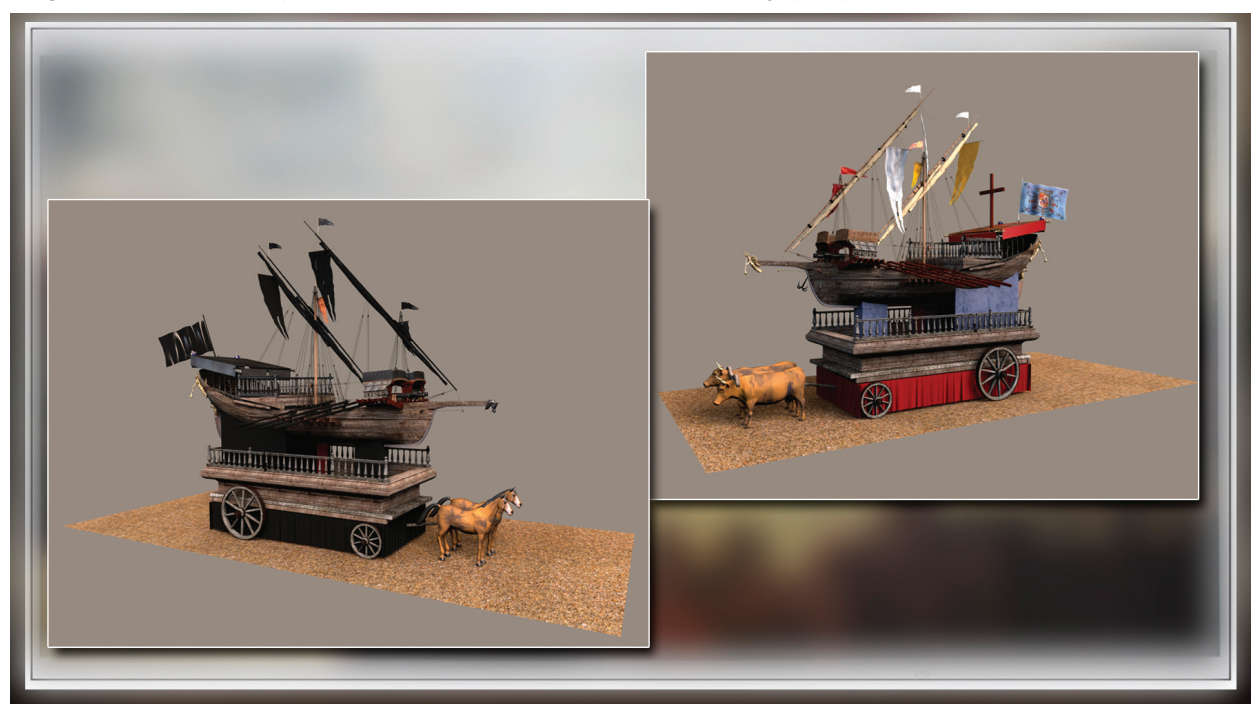

Imagen XIV

La expresión documental «las cuales [galeras] se han de mover a la redonda, de modo que se encuentren» nos ha ocupado mucho tiempo de reflexión. Nos inclinamos a pensar - a diferencia de otros estudiosos - que no alude a un giro de cada galera sobre sí misma, lo que obligaría a un complicado y -en nuestra opinión- innecesario esfuerzo técnico, sino más bien al hecho de que en el trayecto del recorrido, donde una galera avanzaba en pos de la otra, al llegar al espacio abierto de algunos de los lugares elegidos para la representación, los experimentados manipuladores de las mismas debían enfrentarlas, acoplándolas a la plaza de armas -moviéndolas a la 
redonda - para producir el efecto deseado. En similar sentido, ya hemos comentado el empleo del término «aparecen».

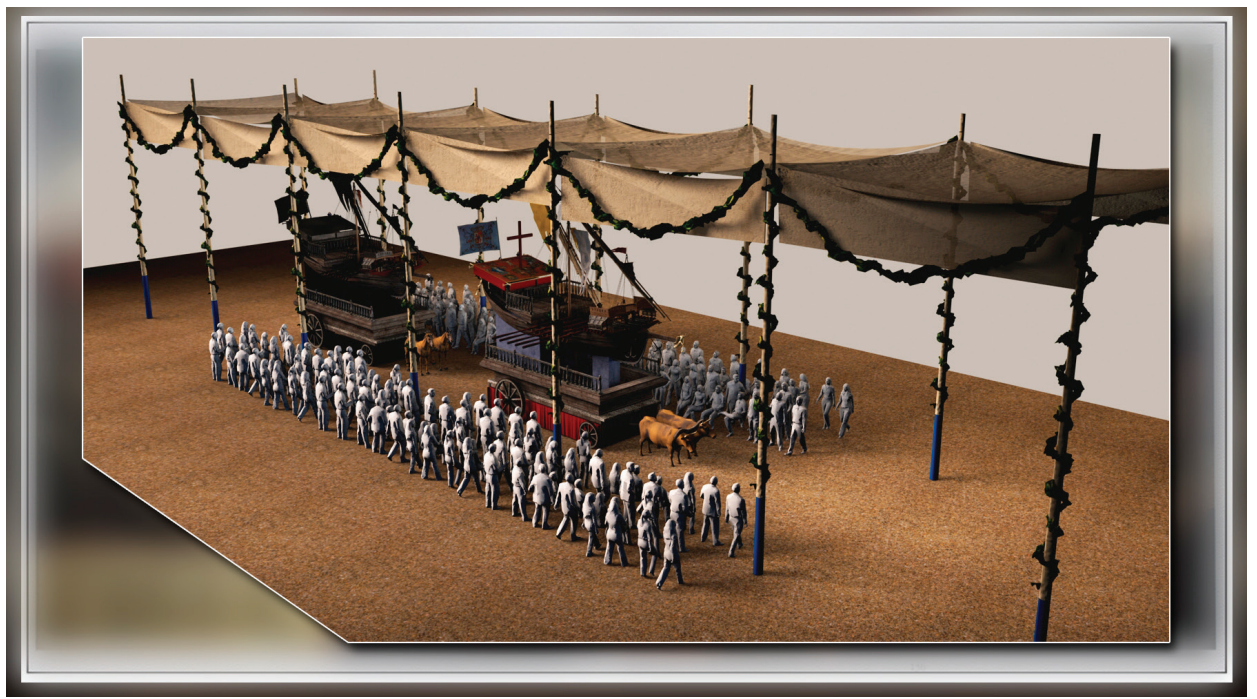

Imagen XV

Como se aprecia, no era sencilla la tarea de los carpinteros, pero no debemos olvidar la más importante de todas, la obligatoriedad de los autores de realizar con sus respectivos carros el recorrido completo de la procesión. Así armados, nuestros dos medios carros recorrerían, junto a los demás dispuestos para este año - un total de diez, recordemos-, el itinerario establecido, ante la atenta mirada de los sevillanos, tras la primera representación de los autos delante de la puerta principal de la catedral. Un itinerario coincidente

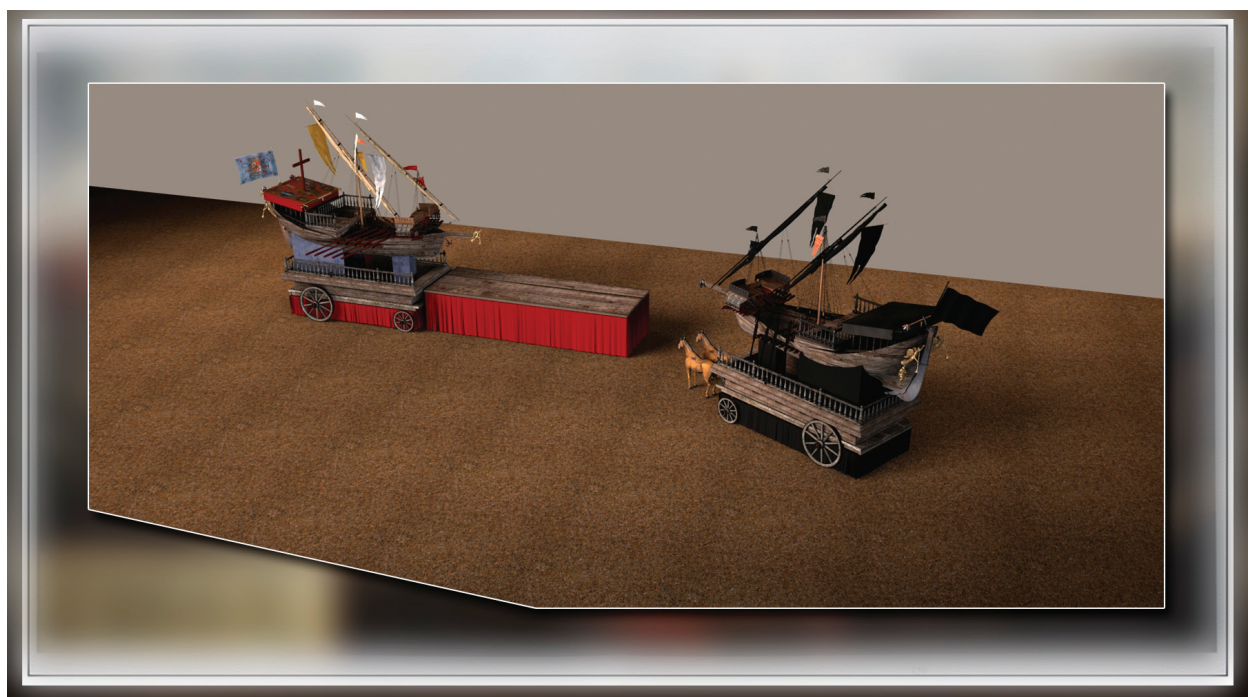

Imagen XVI 


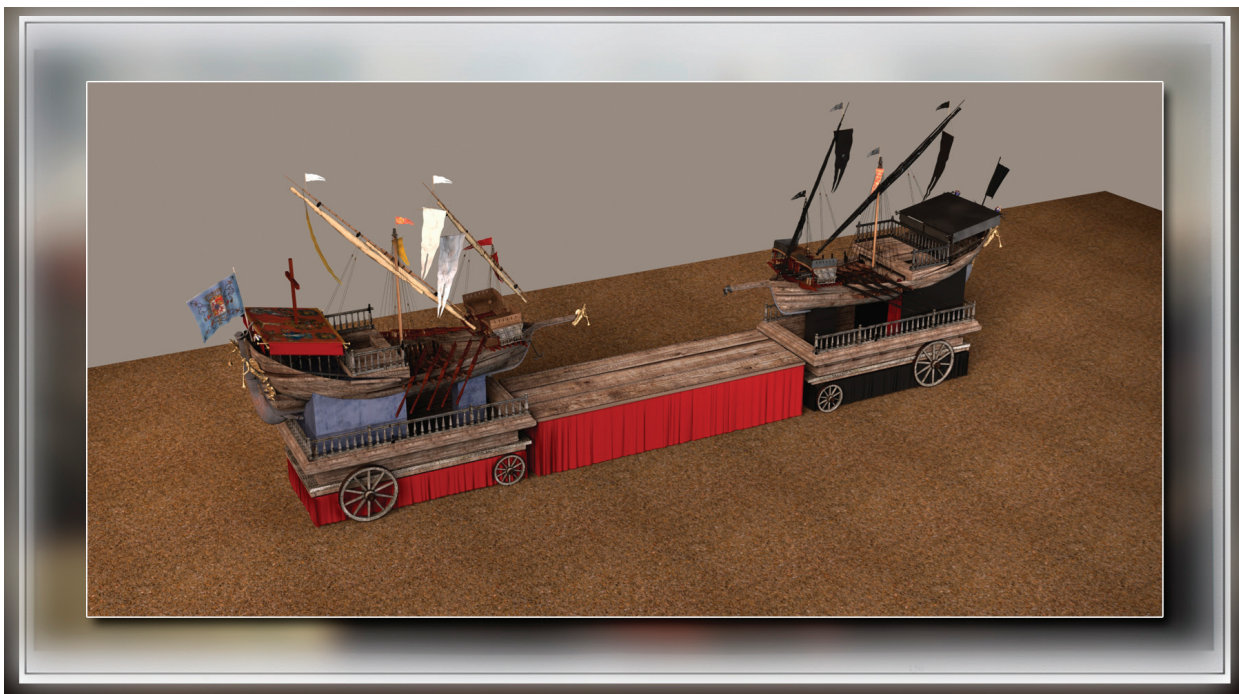

Imagen XVII

año tras año ${ }^{57}$. Si bien la documentación no proporciona explicitamente el seguido en 1619, la distribución de sus calles entre los diputados de la comisión de la fiesta para velar por el mantenimiento del orden, lo perfila de forma diáfana: Gradas [Catedral], calle de Génova [Avda. de la Constitución], Plaza de San Francisco, calle de la Sierpe, Cerrajería, Carpintería [Cuna en la parte más cercana a la Plaza del Salvador], Plaza del Salvador, calle de Culebras [Villegas], Francos y Placentines hasta la puerta de la Torre [Giralda] ${ }^{58}$. Es decir, un itinerario no demasiado distinto al que recorre la procesión en la actualidad, si bien desprovista de toda la parte teatral y parateatral que la acompañaba.

Planimétricamente, no parece que se realizaron cambios significativos en la fisonomía de la ciudad hasta después de la descripción recogida en el plano de Olavide de 1771, lo que nos permite analizar el itinerario y compararlo con el trazado actual mediante planimetría CAD, comprobando que, aun con pequeñas diferencias, no ha sufrido transformaciones de importancia. Itinerario en el que existen dos o tres puntos conflictivos: calle Sierpes-Cerrajería, Cerrajería-Cuna y Villegas-Francos, giros de noventa grados los dos primeros y en el caso del tercero inferior, aunque cuenta con más espacio para acometerlo. El plano CAD del trazado actual y la visita al lugar real nos han permitido comprobar que, con angostura y no sin dificultades, el recorrido de nuestros hipotéticos carros sería viable.

Nos llama la atención no obstante, como hemos comentado, la reiteración en la prevención de accidentes. Aun teniendo en cuenta las posibles irregularidades del terreno, que sería sometido sin duda a una ardua preparación para evitar la rotura

57. Como ejemplo, puede leerse el seguido en el Corpus hispalense de 1575, Reyes Peña, 1995, artículo donde se reconstruye, casi día a día, todos los preparativos que generan la fiesta y su desarrollo (el recorrido urbano, en p. 191).

58. «[Nombramiento de diputados para las calles por donde ha de pasar la fiesta]», Cuadernillo del Corpus de 1619, fol. 296r-v. 


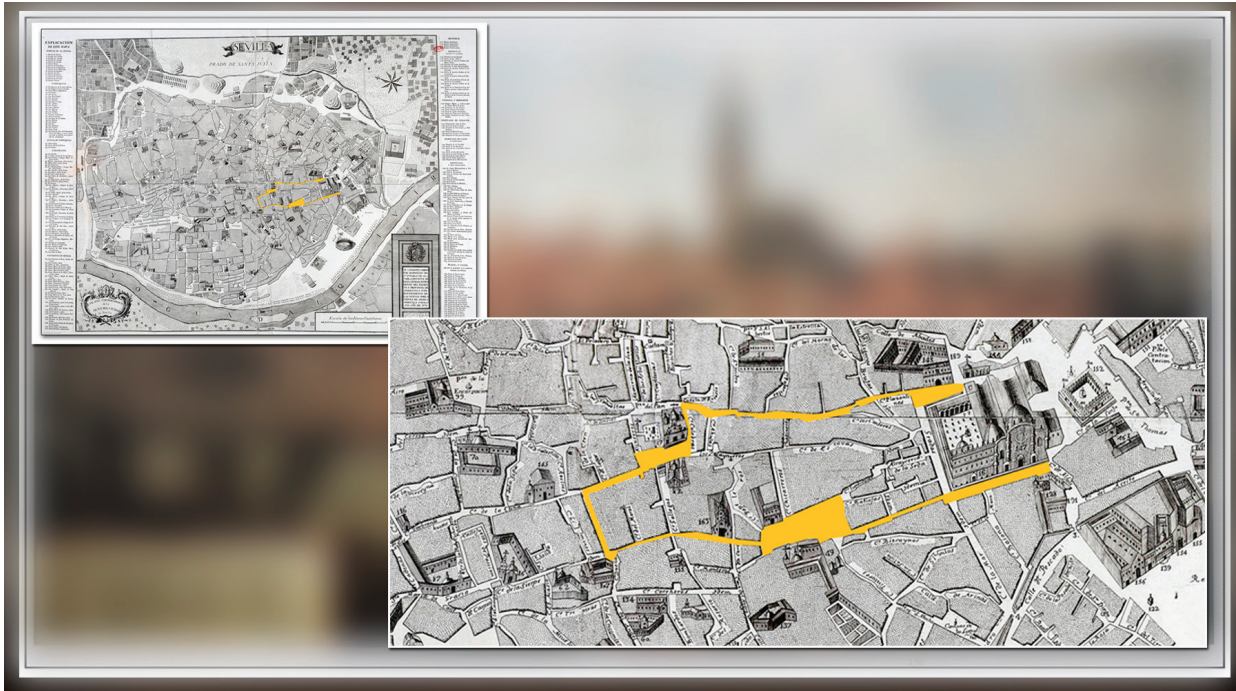

Imagen XVIII

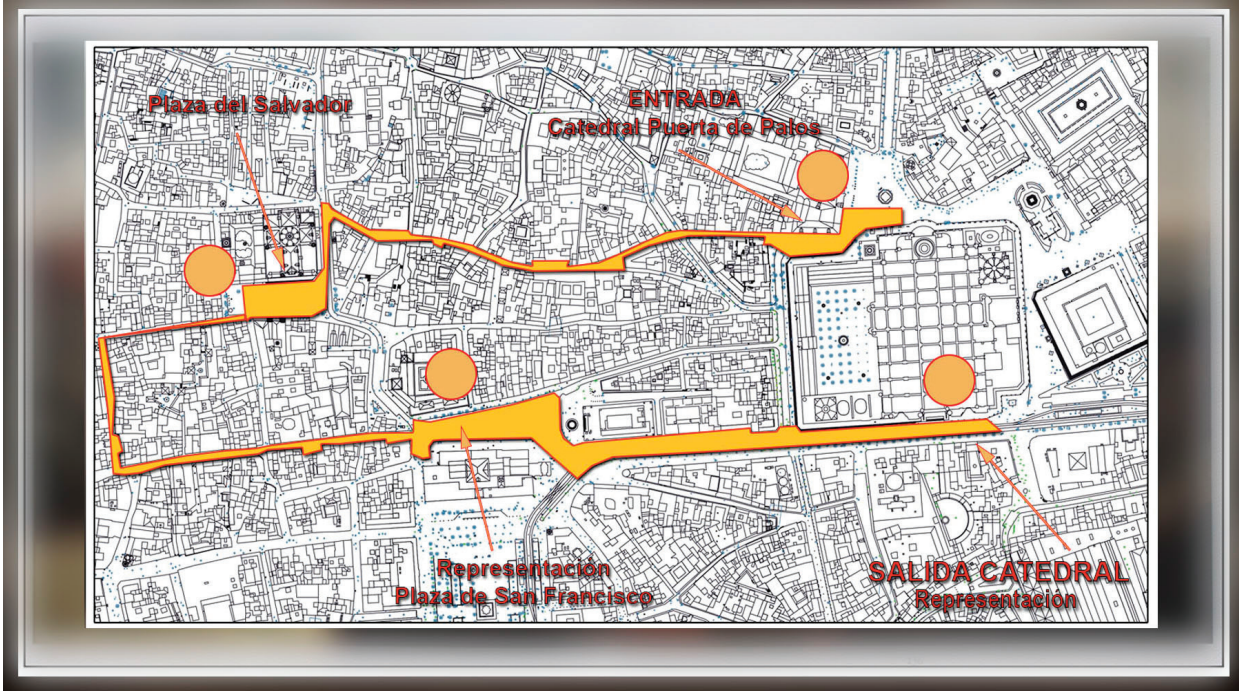

Imagen XIX

de las ruedas que tanto obsesionaba a los organizadores, tal vez debamos pensar en otros motivos que justifiquen la frecuencia de estos accidentes como el excesivo peso de los carros ya armados, con su decoración y tramoyas. Lo que nos reafirma en que el dispositivo era de buen tamaño, dotado de elementos decorativos y técnicos, practicable por los actores y, por tanto, muy pesado.

Nos parece pertinente, por último, ofrecer unas imágenes comparativas de nuestra hipótesis y el dibujo de Sentaurens (1984) que en sección longitudinal describe un carro para el Corpus hispalense. En ambas, podemos apreciar la similitud del dispositivo: una estructura soporte, el carro propiamente dicho; la casa con 


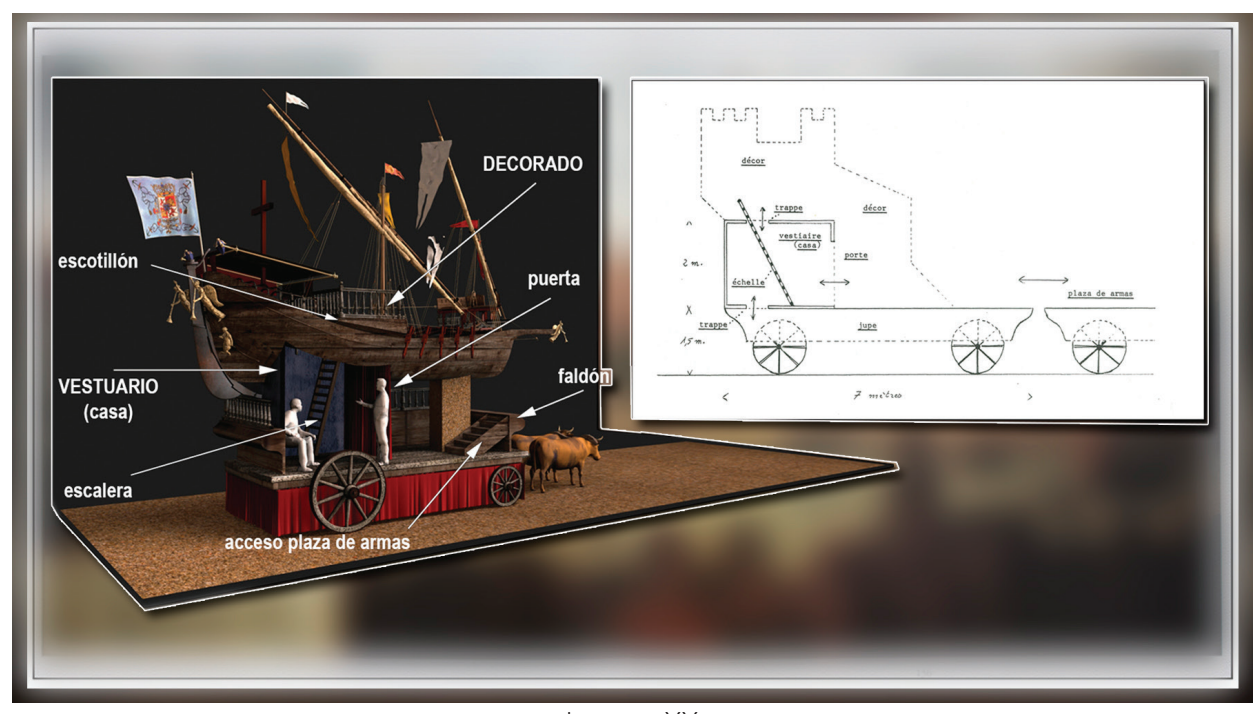

Imagen XX

medidas aproximadas a las citadas; un escotillón para acceder desde el exterior - «trappe» en Sentaurens-; el vestuario con una escalera que permite subir a la parte superior a través de otra trampilla, y, en torno a aquélla, envolviéndola, el decorado, en este caso, un castillo.

Las proporciones en ambos carros son similares. Es fácil imaginar las almenas de ese castillo, o alguna puerta o ventana no expresada en el dibujo, y cómo a través de ella podrían los actuantes ofrecer una variada paleta de recursos escénicos. Como es evidente, el castillo tiene proporciones fuera de la escala real, pero resulta aceptable su aspecto, del mismo modo que nuestra galera. No imaginamos una pequeña nave montada sobre la casa, que pueda girar sobre sí misma, del mismo modo que no parecería verosímil un castillito colocado encima de la casa. La casa, además de servir de vestuario, es el soporte de las estructuras técnicas - las tramoyas - y también de los decorados. Está pensada y planificada para que pueda llegar a tener una envergadura tan importante como para poner en riesgo de rotura las ruedas y ejes que la soportan, a pesar de estar sólidamente construidos. No debemos menospreciar la pericia de los constructores y decoradores que suponemos muy experimentados en resolver exigencias similares. ¡Cómo si no se permitirían los dramaturgos la variada cantidad de demandas que conocemos por los textos de los autos!

Acabada la festividad, la escenografía de los carros se desplazaba desde estos escenarios móviles al fijo de los corrales de comedias, donde se volvían a representar los autos. De ello, da fe para las fiestas eucarísticas de 1619 el conocido cartel que presentamos, conservado en el Archivo Municipal de Sevilla ${ }^{59}$. Se aporta como prueba en una querella criminal interpuesta por Francisco de Rivera, arrendador del Corral del Coliseo, en 5 de junio de 1619, ante el Sr. Juan Muñoz de Escovar del «Consejo e Contaduría mayor de cuentas de Su Majestad, Juez del Desem-

59. Ver Reyes Peña, 1993. 


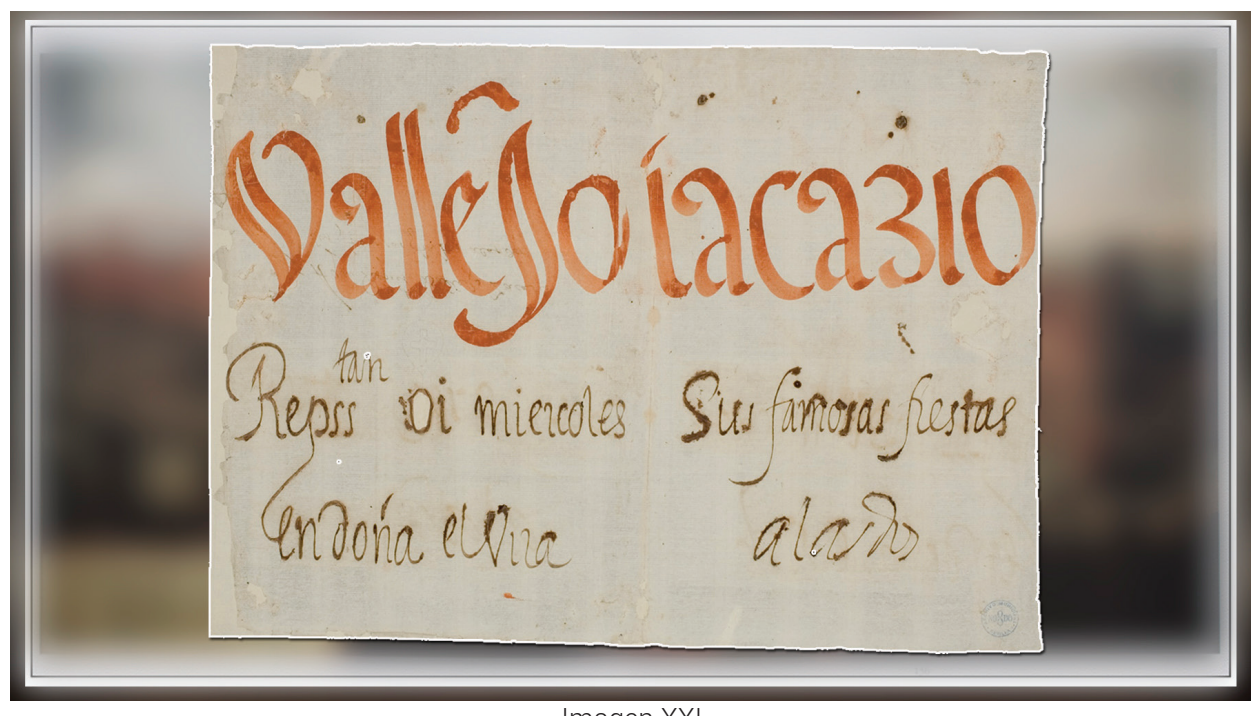

Imagen XXI

peño desta ciudad de Sevilla», contra Juan Acacio y Diego de Vallejo, autores de comedias, por su decisión de representar los autos sacramentales del Corpus en el Corral de doña Elvira, como anunciaban los carteles. Con ello, contravenían lo ordenado por dicho juez que, de acuerdo con una resolución anterior de 25 de mayo, había dispuesto que se representaran en el Corral del Coliseo, cuando los citados autores le pidieron licencia para hacerlos en el Corral de doña Elvira, y

porque semejante desacato no se debe dar lugar, a Vuestra Merced pido y suplico mande prender a los dichos autores de comedias, que son Juan Acacio y Diego de Vallejo, y quitar los carteles que están puestos, ejecutándoles por las penas en que han incurrido y en los daños que a la hacienda desta ciudad por la dicha causa se le han seguido y siguen [recordemos que el Corral del Coliseo era de propiedad municipal], y pido justicia. Ansí para en prueba de lo susodicho, hago demostración de uno de los carteles que los susodichos han puesto por las esquinas y del auto por Vuestra Merced proveído y notificaciones, y pido justicia... ${ }^{60}$.

Prueba ésta a la que se suma el testimonio de un escribano, al que el juez, «para mejor prover», ordena que vea los carteles que están puestos cerca del Corral de doña Elvira e lo ponga por diligencia»; y las declaraciones de dos testigos que, además de haberlo visto por «los carteles que están fijados en las esquinas», lo han sabido así, el primero, en el Corral de doña Elvira, «de las personas que alquilan aposentos», y, el segundo, porque lo ha oído decir en dicho corral ${ }^{61}$. Como se deduce de este testimonio, las «famosas fiestas del Corpus», es decir, los autos sacramentales de los autores Vallejo y Acacio, eran susceptibles de adaptarse para su representación al escenario de uno u otro corral.

60. Reyes Peña, 1993, p. 101. En las citas documentales modernizamos, como ya se ha indicado 61. Reyes Peña, 1993, p. 101 
Este bello y exclusivo cartel pone fin a nuestra exposición, con el deseo de haber mostrado el ambiente festivo y la compleja organización que se desarrollaba en torno al Corpus Christi en una urbe como Sevilla, que competía con otras ciudades de España por celebrar con el mayor esplendor posible este homenaje a la Eucaristía.

\section{BIBLIOGRAFÍA}

Arias, Ricardo (ed.), Autos sacramentales (El auto sacramental antes de Calderón), México, Porrúa, 1977.

Arias, Ricardo y Robert V. Piluso (ed.), José de Valdivielso, Teatro completo, Madrid, Isla, vol. I, 1975.

Aut. $=$ Diccionario de Autoridades, Madrid, Real Academia Española, 1726-1739. Ed. facs.: Madrid, Gredos, 1984. Real Academia Española, Nuevo Tesoro Lexicográfico de la Lengua Española. Disponible en línea: <http://ntlle.rae.es> [16/10/2017]

Bernáldez Montalvo, José María, Las tarascas de Madrid, Madrid, Ayuntamiento de Madrid, 1983.

Bolaños Donoso, Piedad y Mercedes de los Reyes Peña (ed)., Una mascarada jocoseria en la Sevilla de 1742, con apéndice de Emma Falque, Sevilla, Universidad de Sevilla, 1992, ed. facsímil.

DRAE = Real Academia Española, Diccionario de la Lengua Española, Disponible en línea: <http://dle.rae.es> [16/10/2017].

Díez Borque, José María, «Introducción», en Pedro Calderón de la Barca, Una fiesta sacramental barroca. Loa para el Auto. Entremés de los instrumentos. Auto sacramental La segunda esposa y triunfar muriendo. Mojiganga de las visiones de la muerte, ed. José María Díez Borque, Madrid, Taurus, 1984.

González Pedroso, Eduardo (ed.), Autos sacramentales desde su origen hasta fines del siglo XVII [1865], Madrid, Atlas, 1952.

Marcello, Elena, «Valdivielso, José de», en Diccionario Filológico de Literatura Española Siglo XVII, dir. Pablo Jauralde Pou, coords. Delia Gavela y Pedro C. Rojo Alique, Madrid, Castalia, 2010, vol. 2, pp. 556-576.

Parker, Alexander A., Los autos sacramentales de Calderón de la Barca [1943], Barcelona, Ariel, 1983.

Reyes Peña, Mercedes de los, «Los carteles de teatro en el Siglo de Oro», Criticón, 59, 1993, pp. 99-118.

Reyes Peña, Mercedes de los, «El auto sacramental en la segunda mitad del siglo XVI: El Aucto de los desposorios de Joseph del Códice de Autos Viejos», en La puesta en escena del teatro clásico, ed. José María Ruano de la Haza, Cuadernos de Teatro Clásico, 8, 1995, pp. 181-200. 
Rodríguez García, Eva, La puesta en escena de Lope de Vega, Oviedo, Universidad de Oviedo, 2014. Tesis doctoral, disponible en línea: <http://digibuo.uniovi.es/ dspace/handle/10651/25565> [16/10/2017].

Sánchez-Arjona, José, El teatro en Sevilla en los siglos XVI y XVII (Estudios históricos), Madrid, Establecimiento Tipográfico de A. Alonso, 1887. Ed. facs.: Sevilla, Centro Andaluz de Teatro/Editorial Padilla Libros, 1989.

Sánchez-Arjona, José, Noticias referentes a los anales del teatro en Sevilla desde Lope de Rueda hasta fines del siglo XVII, Sevilla, Imp. de E. Rasco, 1898. Ed. facs.: Sevilla, Ayuntamiento, 1994, con prólogo y apéndice bibliográfico de Piedad Bolaños Donoso y Mercedes de los Reyes Peña.

Sentaurens, Jean, Séville et le théâtre de la fin du Moyen Âge à la fin du XVIIe siècle, Bordeaux, Presses Universitaires, 1984, 2 vols.

Shergold, Norman D. y John E. Varey, Los autos sacramentales en Madrid en la época de Calderón: 1637-1681. Estudio y documentos, Madrid, Ediciones de Historia, Geografía y Arte, 1961.

Valdivielso, José, La amistad en el peligro, Bilbao, El Mensajero del Corazón de Jesús, 1922.

Valdivielso, José, «La amistad en el peligro. Acto sacramental», en Autos sacramentales desde su origen hasta fines del siglo XVII [1865], ed. Eduardo González Pedroso, Madrid, Atlas, 1952, pp. 230-244.

Valdivielso, José, «La amistad en el peligro. Acto sacramental», en Teatro completo, ed. Ricardo Arias y Robert V. Piluso, Madrid, Isla, vol. I, 1975, pp. 207-250.

Valdivielso, José, «La amistad en el peligro. Auto sacramental», en Autos sacramentales (El auto sacramental antes de Calderón), ed. Ricardo Arias, México, Porrúa, 1977, pp. 273-303.

Varey, John E., «La mise en scène de l'auto sacramental à Madrid au XVIe et XVII siècles», en Le lieu théâtral à la Renaissance [Royaumont, 22-27 mars 1963], ed. Jean Jaquot, Paris, CNRS, 1986, reimp. de la $2^{\text {a }}$ ed. [1968].

\section{REFERENCIAS A LAS IMÁGENES: NUMERACIÓN, IDENTIFICACIÓN Y LOCALIZACIÓN}

Imagen I. Firmas de actores de la compañía de Diego de Vallejo para el Corpus hispalense de 1619 (Archivo Municipal de Sevilla, Sección XIII, Papeles importantes del siglo XVII, t. II, doc. núm. 36, Cuadernillo del Corpus de 1619, fol. 188v).

Imagen II. Corte esquemático de un medio carro; Corte esquemático de la disposición de los carros; y Plano esquemático de la disposición de los carros (Jean Sentaurens, Séville et le théâtre de la fin du Moyen Âge à la fin du XVIle siècle, Bordeaux, 1984, t. II, pp. 853, 849 y 848). 
Imagen III. Modelo de carro («medio carro») para la representación de los autos sacramentales en Madrid, 1646 (José M. ${ }^{a}$ Bernáldez Montalvo, Las tarascas de Madrid, Madrid, 1983, p. 16).

Imagen IV. Paso de Nuestro Padre Jesús del Silencio en el desprecio de Herodes, de la Hermandad de la Amargura, y paso de La Exaltación, de la Hermandad de la Exaltación, de la Semana Santa de Sevilla.

Imagen V. Reconstrucción de la representación de La adúltera perdonada de Lope de Vega, Madrid, 1608 (John E. Varey, «La mise en scène de l'auto sacramental à Madrid au XVle et XVIle siècles», en Le lieu théâtral à la Renaissance..., ed. Jean Jaquot, Paris, 1986, reimp. de la $2^{\text {a }}$ ed. [1968], fig. 4).

Imagen VI. El Ommeganck en Bruselas, el 31 de mayo 1615: El triunfo de la archiduquesa Isabel, por Denys van Alsloot, 1616 (London, Victoria and Albert Museum, en línea, 02/11/201).

Imagen VII. Carros Serio y Jocoso de la Máscara Joco-seria del Colegio Mayor de Santo Tomás de Aquino, el 2 de mayo de 1742, en Sevilla (Piedad Bolaños Donoso y Mercedes de los Reyes Peña [eds.], Una Mascarada Joco-seria en la Sevilla de 1742, con apéndice de Emma Falque, Sevilla, 1992, ed. facs., imágs. entre págs. 60-61 y 36-37).

Imagen VIII. Carros del Víctor, Carro del Parnaso y Carro del Agua, por Domingo Martínez, 1748-1749 (Sevilla, Museo de Bellas Artes, óleo sobre lienzo).

Imagen IX. Diversos tipos de carros.

Imagen X. Rocas o carros triunfales del Corpus de Valencia.

Imagen XI. Galera ('carro') [Reconstrucción virtual].

Imagen XII. Plataforma del carro con casa sobre ella (Reconstrucción virtual).

Imagen XIII. Galeras en la batalla de Lepanto (1571).

Imagen XIV. Galera de Gloria o Gracia y Galera Infernal o del Deleite (Reconstrucción virtual).

Imagen XV. Galeras en procesión bajo entoldado (Reconstrucción virtual).

Imagen XVI. Anexión de las galeras a la plaza de armas (Reconstrucción virtual).

Imagen XVII. Galeras en la plaza de armas (Reconstrucción virtual).

Imagen XVIII. Recorrido en el plano topográfico de la ciudad de Sevilla, mandado realizar por Pablo de Olavide, 1771 (Archivo Municipal de Sevilla).

Imagen XIX. Recorrido en el plano de la Sevilla actual.

Imagen XX. Comparativa de la Galera de Gloria o Gracia (reconstrucción virtual) con el dibujo del corte esquemático de un medio carro realizado por Sentaurens (Séville et le théâtre..., t. II, p. 853).

Imagen XXI. Cartel sevillano de 1619 (Sevilla, Archivo Municipal, I-155-290). 